\title{
PEARLY TUMOURS IN RELATION TO THE CENTRAL NERVOUS SYSTEM
}

\author{
BY \\ JOHN S. TYTUS and JOE PENNYBACKER \\ From the Department of Neurological Surgery, Radcliffe Infirmary, Oxford
}

In 1829 Cruveilhier described a growth found at the base of the brain, displacing the third ventricle superiorly and extending as far anteriorly as the sella turcica (Fig. 1). Its external surface was of a " metallic sheen like silver-or like a pearl of the finest water". The contents of the growth were analysed by Bannel and " presented all the characters of cholesterin". Cruveilhier also discussed a similar lesion reported a year before by La Prestre and one supposedly from Dupuytren's clinic exhibited as a wax model by Dumeril in 1807 . Because of their striking external appearance he called them pearly tumours.

Verattus in 1745 is said to be the first to record such a lesion when he found at necropsy a brain tumour containing masses of hair.

Müller (1838) reported two examples and, because of the nature of their contents, named them cholesteatomas.

Virchow (1855) discussed a number of these cases, but because he failed to demonstrate cholesterin in all of them believed the term " pearly tumour" to be more suitable.

The origin of these tumours remained obscure until 1854, when von Remak suggested that they might arise from misplaced epithelial tissue. This work was substantiated by Bostroem, who in 1897 agreed with their epithelial origin. He thought that growths, which he termed "pial epidermoids", arose from embryonic skin elements at a comparatively late stage, whereas the pial dermoids arose from cell rests included earlier in embryonic life.

In 1920 Bailey, in a full discussion of these tumours, mentioned two examples, similar to Bostroem's pial epidermoids, operated upon by Cushing, but because of the existing confusion concerning their origin he retained the name " pearly tumour".

We also prefer this term and include under this heading growths of both epidermal and dermal origin, that is to say, epidermoids and dermoids.

\section{Origin}

It is now generally accepted that these tumours arise from epithelial rests that result from defective closure of the neural tube between the third and fifth week of embryonic life. Foetal implantations early in this period tend to lie in the midline, especially in the creases between the primary cerebral vesicles. If they occur later, during the formation of the secondary cerebral vesicles, they tend to lie laterally away from the midline (Bostroem, 1897). Should implantation occur after the cerebral cortex and cerebellum have formed, the rests may be deposited in mesodermal structures between skin and brain and give rise to the epidural, intradiploic, and pericranial tumours (Harvey and Burr, 1926; Rand and Reeves, 1943).

If the cleavage of cutaneous and neural ectoderm remains incomplete at a certain point a dermal sinus will develop connecting the external skin with the neuraxis (List, 1941; Walker and Bucy, 1934).

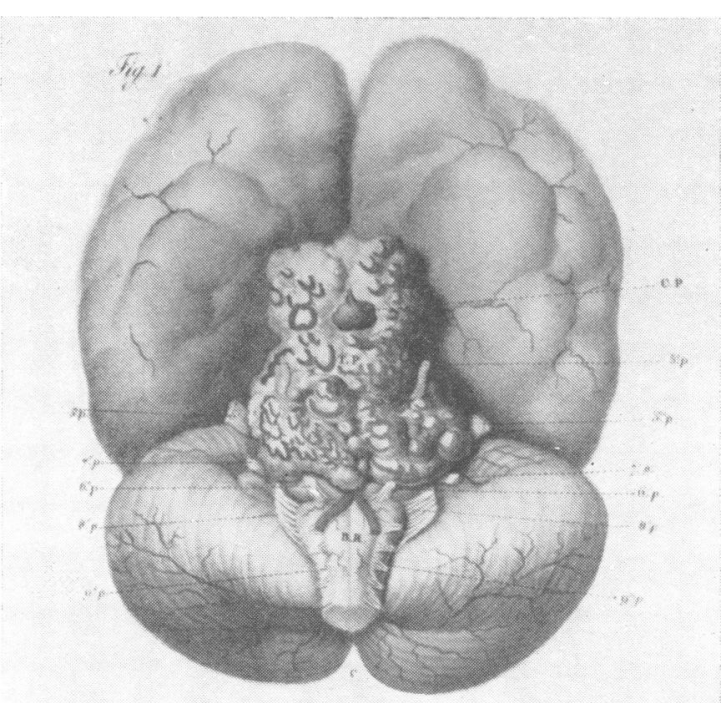

Fig. 1.-Reproduction of an illustration of Cruveilhier's case of a pearly tumour arising at the base of the brain.

[From Cruveilhier, Anatomic Pathologique du Corps Humain, Vol. I, Book 2, Plate 6.] 


\section{Appearance}

Grossly, the epidermoids and dermoids are quite similar. Their most characteristic feature lies in the appearance of the capsule, which typically is opaque, white, and glistening. Variations in colour do occur, however, especially in the dermoids. They may be grey, yellow, green, brown, or even red (King, 1939).

The main tumour mass is made up of epithelial debris which slowly accumulates within the capsule from desquamating cells of the epithelial lining. It contains fatty material and cholesterol, and in the case of the dermoids sebaceous material and hair. The consistency depends upon the proportions of these substances (Brock and Klenke, 1931). It is usually caseous or like soft butter, but, especially in the dermoids, may be cystic, containing oily or opalescent yellow fluid.

The capsule is a thin membrane which, in the case of epidermoids, consists of an epidermal layer without dermal structures (Fig. 11). Dermoids, on the other hand, have a capsule composed of epidermis, together with a dermal layer containing hair and sebaceous glands (Fig. 19). Fat and connective tissue may also be present.

Both types seem similar to the naked eye, and since their characteristics are the same as regards growth, recurrence, and complications, it seems unnecessary to make a sharp distinction between the two (Bailey, 1924; Bostroem, 1897; Critchley and Ferguson, 1928; Horrax, 1922; Montgomery and Finlayson, 1934).

\section{Characteristics}

They are benign encapsulated tumours that usually do not invade surrounding regions. Raskin (1949), however, described a case in which an

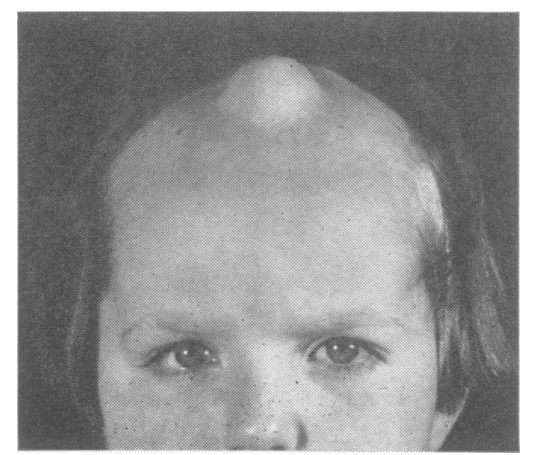

Fig. 2

FIG. 2.-Photograph of a child (R.I. 53428/46) with a pericranial dermoid. Note its midline position and its relation to the anterior fontanelle.

FIG. 3.-Skull radiograph (same case) showing bony defect in a pericranial dermoid. Note smooth edges that appear to be eroded from without inwards. The tumour itself can also be seen. epidermoid had directly infiltrated the brain, a cites other examples. Rarely, they undergo malignant change (Ernst, 1912; Hug, 1942; Stromeyer, 1909). They are extremely slow-growing an⿳亠口冋, depending on their location, may attain a tremerf. dous size before any signs of their presence appes. Occasionally, they become calcified (Peyton am Baker, 1942; Rand and Reeves, 1943).

Their incidence ranges between 0.3 and $1.8 \%$ in various reported series of tumours of the centri: nervous system (Findeisen and Tönnis, 1937; King, 1939; Mahoney, 1936; Sachs and Horrax, 1948; Walker and Bucy, 1934).

\section{Clinical Data}

This series comprises a total of 41 cases of verified epidermoids and dermoids, most of which were seân at the Radcliffe Infirmary. Four patients, however, were treated at the London Hospital, and two wes operated upon at St. Hugh's Military Hospital during the war.

Although theoretically they may occur at almost any site in the central nervous system, certain locations are more common. They most frequenify occur in the subarachnoid cisterns at the base opthe brain, but are not infrequently found in the Begcranial, orbital, petrous, and diploic regions and in the cerebello-pontine angle. They are also seen the substance of the cerebral cortex, cerebel and in the spinal canal.

Pericranial.-These growths were found incivo children (R.I. Nos. 53428/46 and 177532) 3 and des years of age. Each presented with a mass near the midline over the vertex of the skull in the region of the anterior fontanelle (Fig. 2). This had been

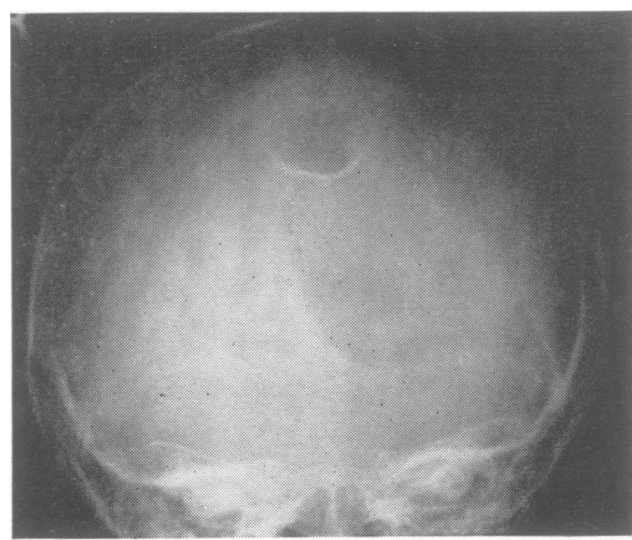

FIG. 3 
Fig. 4.-Drawing to show the usual location of an orbital dermoid and its relation to the glove and periorbital structures.

[From Cairns, H. "Peripheral Ocular Palsies from the Neuro. surgical Point of View," Trans. ophthal. Soc. U.K., 1938, 58, 464-482 (Fig. 172). By permission of the Editor.]

Fig. 5.-Skull radiograph showing the characteristic appearance of an orbital pearly tumour (Case 2). There is a circumscribed erosion of the left supra-orbital ridge and the margins of the defect are smooth and thickened.

present since birth in each case and had gradually increased in size. There were no neurological abnormalities.

Skull radiographs revealed a round bony defect that appeared to erode both the inner and outer tables (Fig. 3). In both cases the cortex of the bone appeared to be eroded from without in. This particular characteristic aids in the differentiation of these lesions from encephaloceles and also raises a point in aetiology. The apparent origin of these tumours from the pericranium substantiates the work of Harvey and Burr (1926), who proved that the neural crest contributes ectodermal elements to the mesoderm that take part in the formation of the meninges. Epithelial implantations in relation to the dura or the pericranium therefore become understandable.

The tumours were removed easily and without event. Their gross appearance was characteristic. Histological examination of both specimens revealed them to be dermoids.

Orbital.-These tumours usually arise from the lateral orbital roof (Fig. 4).

They tend to grow very slowly, displacing the eye downwards and slightly medially, and are characterized by unilateral proptosis of long duration without neurological symptoms. Visual acuity is often unaffected and, because of their slow growth, these lesions rarely cause double vision.

Six patients in this series had orbital pearly tumours (Table I). Proptosis was the main complaint in all cases. In five it was painless. One patient (Case 3) also complained of headaches, but the neoplasm had extended posteriorly to involve the sphenoidal ridge. The length of the history varied from 15 months to 20 years, the average duration of symptoms being about four years.

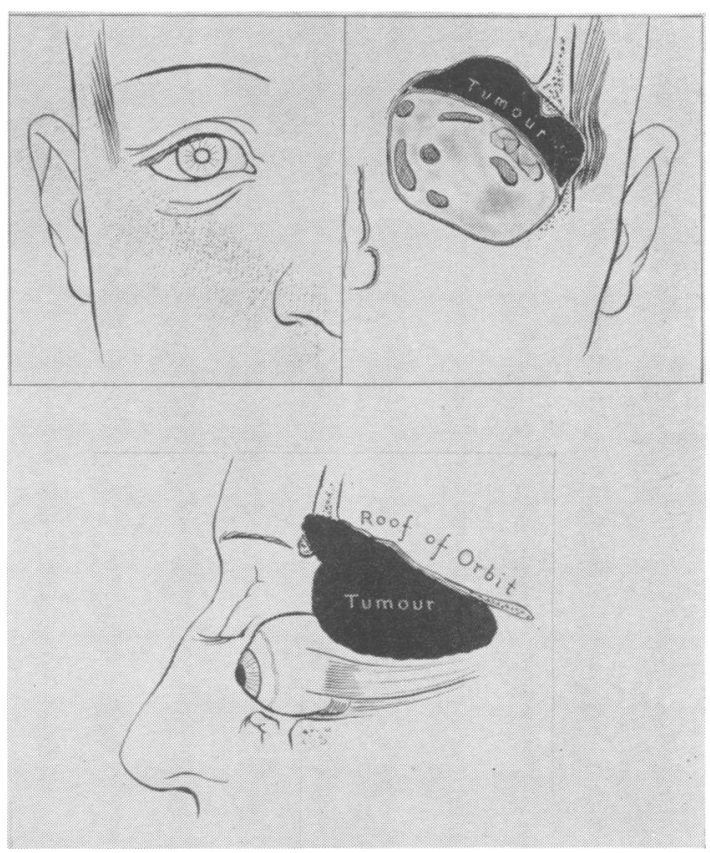

FIG. 4

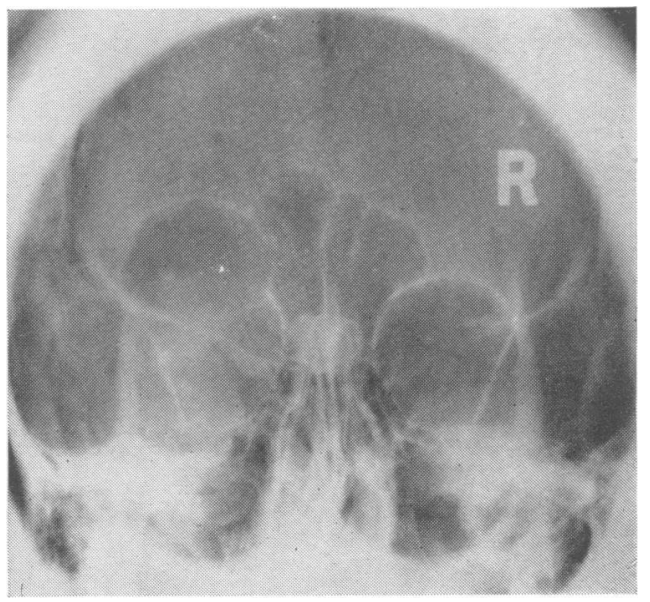

FIG. 5

TABLE I

ORBITAL PEARLY TUMOURS

\begin{tabular}{|c|c|c|c|c|c|c|c|c|c|}
\hline & Age & Sex & $\mid \begin{array}{c}\text { Duration } \\
\text { of Symptoms } \\
\text { (yr.) }\end{array}$ & $\begin{array}{c}\text { Visual } \\
\text { Loss }\end{array}$ & Diplopia & $\left|\begin{array}{c}\text { C.S.F. } \\
\text { Protein } \\
(\mathrm{mg} . / 100 \mathrm{ml} .)\end{array}\right|$ & $\begin{array}{l}\text { Estimated } \\
\text { Removal }\end{array}$ & Type & $\begin{array}{c}\text { Years } \\
\text { Followed }\end{array}$ \\
\hline $\begin{array}{l}\text { 1. J.H., L.H. } \\
\text { 2. E.B. (R.I. No. } 3966 / 43 \text { ) } \\
\text { 3. G.G. (R.I. No. } 48074 / 45 \text { ) } \\
\text { 4. A.M. (R.I. No. 100641/49) } \\
\text { 5. R.C. (R.I. No. 127413) }\end{array}$ & $\begin{array}{l}57 \\
38 \\
28 \\
36 \\
29\end{array}$ & $\begin{array}{l}\mathbf{M} \\
\mathbf{F} \\
\mathbf{F} \\
\mathbf{M}\end{array}$ & $\begin{array}{r}7 \\
20 \\
2 \\
6 \\
7\end{array}$ & $\begin{array}{l}\text { No } \\
\text { No } \\
\text { No } \\
\text { Yes } \\
\text { Yes }\end{array}$ & $\begin{array}{l}\text { Yes (mild) } \\
\text { Yes (mild) } \\
\text { No } \\
\text { No } \\
\text { No }\end{array}$ & $\begin{array}{l}45 \\
43 \\
\overline{30}\end{array}$ & $\begin{array}{l}\text { Complete } \\
\text { Complete } \\
\text { Complete } \\
\text { Complete } \\
\text { Complete }\end{array}$ & $\begin{array}{l}\text { Dermoid } \\
\text { Epidermoid } \\
\text { Epidermoid } \\
\text { Dermoid } \\
\text { No capsule } \\
\text { found }\end{array}$ & $\begin{array}{l}10 \\
13 \\
\frac{11}{6}\end{array}$ \\
\hline 6. F.P. (R.I. No. 213947) & 24 & $\mathbf{M}$ & $1 \frac{1}{2}$ & No & No & 25 & Complete & Dermoid & $\frac{1}{2}$ \\
\hline
\end{tabular}




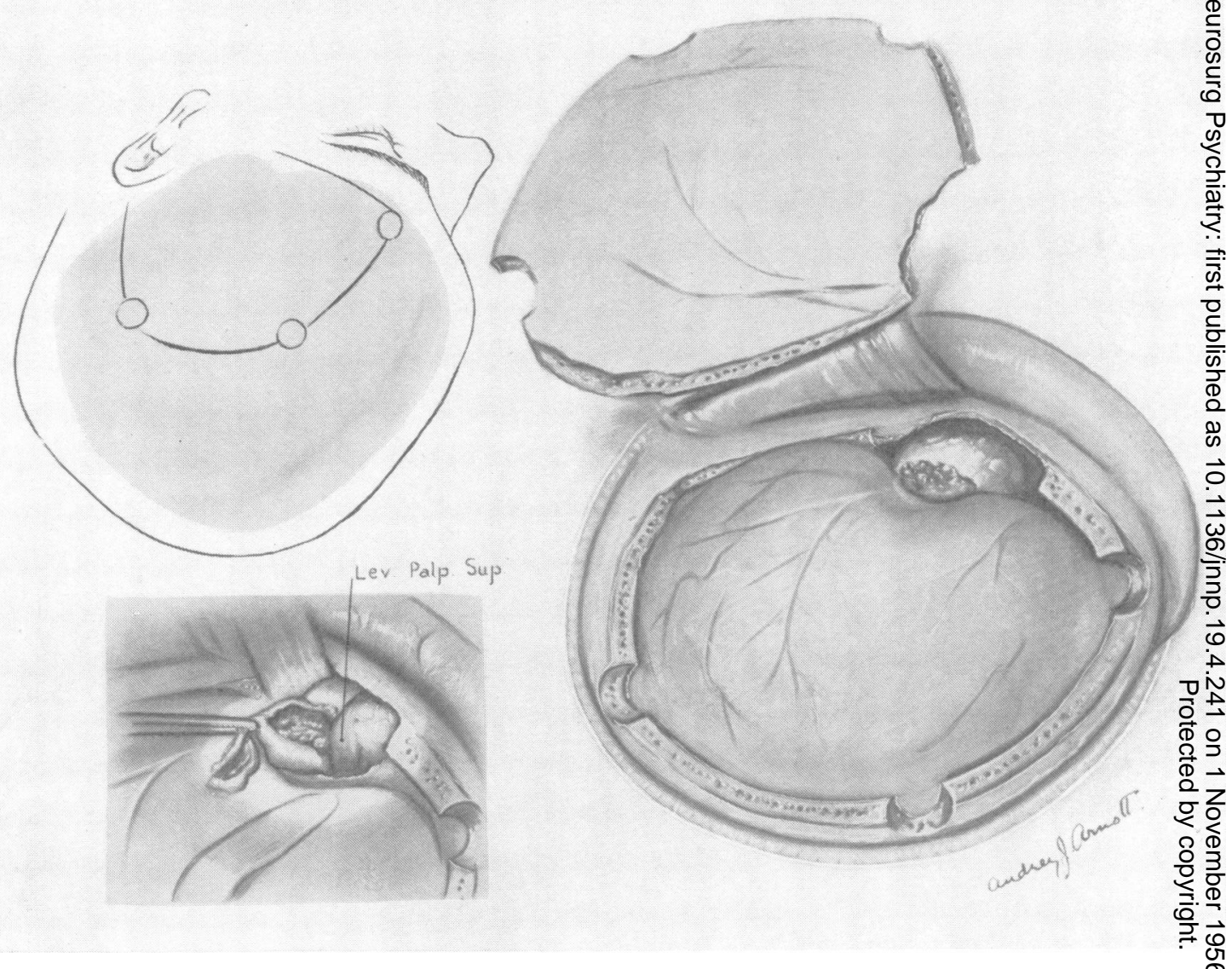

FIG. 6.-Drawing of the operative approach to an orbital pearly tumour. A frontal flap is turned and the orbit is unroofed. exposing the anterior fossa intracranial extensions of these tumours can also be dealt with.

Visual acuity was normal in four patients. In two cases there was moderate visual loss, without demonstrable scotoma or other evidence of optic nerve involvement. In one, vision had returned to normal at the time of discharge, and it was presumed that the previous visual loss had been a factor of the proptosis. None of these patients complained of double vision, but in two of them it could be elicited by upward movement of the eyes.

As one would expect, the cerebrospinal fluid protein level, obtained in four patients, was not elevated in any of them.

Orbital radiographs usually reveal a circumscribed area of erosion of the supraorbital ridge (Fig. 5). The margins of the defect tend to be rounded, smooth, and thickened, evidence of long-standing involvement. There may be scalloping of the edges, and trabeculation is occasionally seen.

The unsightly proptosis constitutes the chief indication for surgical removal of these tumours.
They can best be dealt with through a frongl craniotomy approaching the orbit from abo: (Fig. 6). This affords access to the anterior fos in the event that an intracranial extension is found.

Total removal is usually possible and was believod to have been achieved in all of these cases. There have been no known recurrences to date. From cosmetic standpoint gratifying results may be obtained (Figs. 7 and 8 ).

Histologically, three of the tumours were dermoi two were epidermoids, and in the sixth patient go capsule was available.

Petrous.-Only brief mention will be made of the petrous tumours, since three examples have already been reported by one of us (Pennybacker, 1944). $\supset$

The patients usually present themselves with $\mathrm{S}_{\mathrm{a}}$ progressive peripheral facial nerve paralysis, usuatiy associated with deafness and absent caloric responsess on the same side. There are seldom other neuriglogical abnormalities, and the cerebrospinal flum 
Fig. 7.-Pre- and post-operative photegraphs of a patient with an orbital dermoid (Case 4).

FIG. 8.-Pre- and post-operative photographs of a patient with an orbital dermoid (Case 5). There was some visual loss but in spite of the marked displacement of the left eye he did not complain of diplopia. The last photograph was taken six years post-operatively.

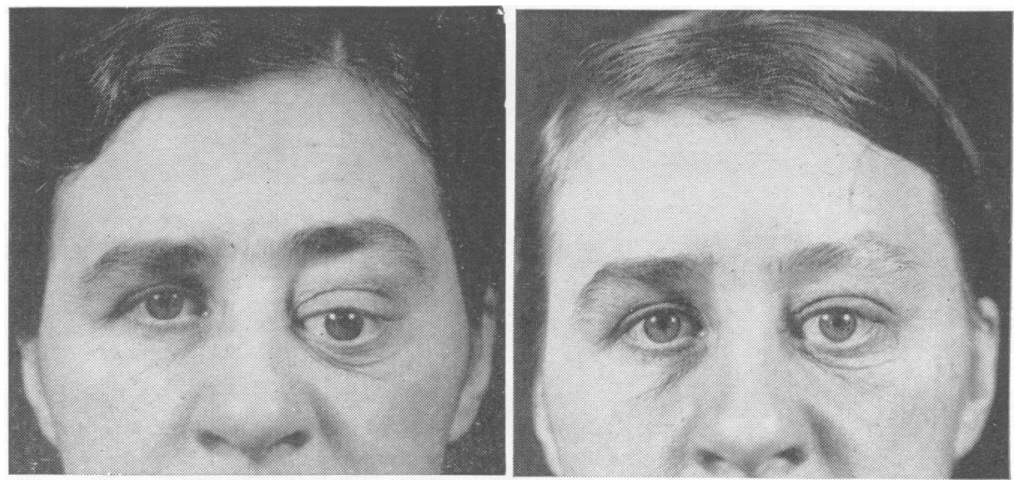

FIG. 8

FIG. 7
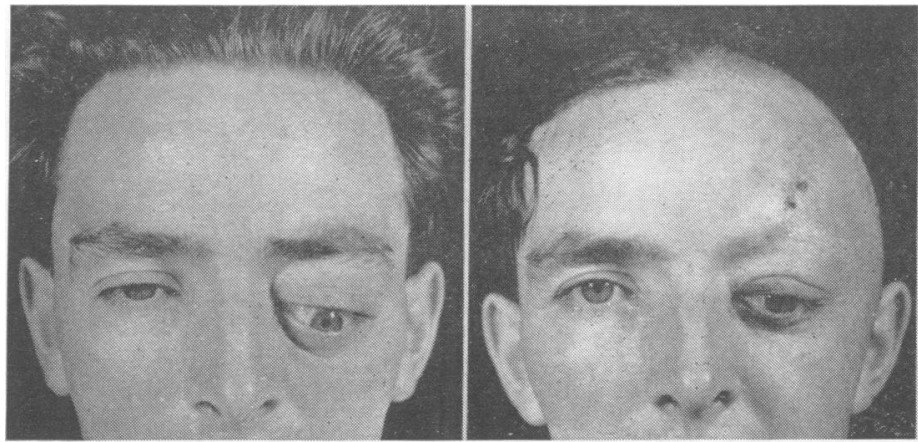

protein is usually normal. There is frequently a past history of ear infection.

These patients are usually thought to be suffering from Bell's palsy, although the gradual onset and progression of the paralysis clearly indicate a different aetiology. Moreover, skull radiographs reveal erosion of the petrous bone that is quite characteristic (Fig. 9).

Cerebello-pontine angle tumours can be ruled out

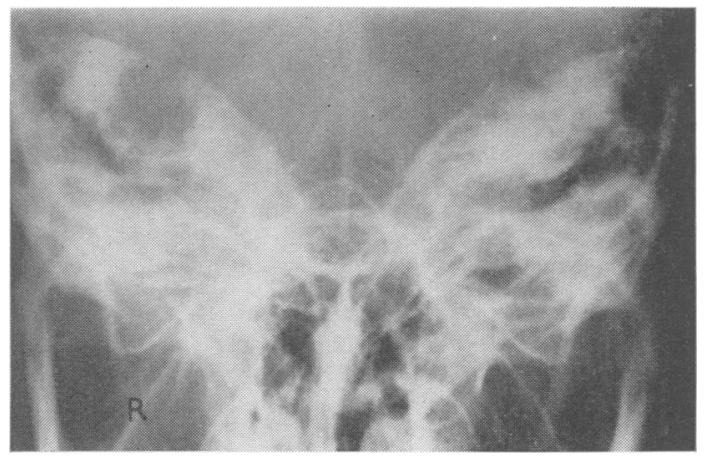

FIG. 9.-Skull radiograph of a patient with a pearly tumour involving the right petrous bone (Case 6). Pre-operatively he still retained a vestige of facial nerve function. After operation, however, there was complete paralysis, although the nerve remained in continuity. Exposure was gained through the endaural mastoid approach. by the absence of cerebellar signs and fifth nerve involvement and by the normal cerebrospinal fluid protein.

We have encountered six cases (Table II). Four of them had a past history of ear infection. In addition, one man (Case 1) had an episode of acute otitis media after the onset of facial weakness. The ear drums in all five of these patients were scarred, and in two of them perforations were present. There had never been any history of ear infection in the other patient (Case 5), and indeed he was not deaf. Total deafness, associated with absent caloric responses, was found in five patients. In the other, there was no deafness by gross testing. All of them had facial nerve paralysis, and in only one was it incomplete. The cerebrospinal fluid protein, available in five cases, was normal in all of them.

The location of these tumours is such that they can often be totally removed. This can best be accomplished through the temporal route or the combined temporal and mastoid approach, depending on their location in the petrous bone as determined by radiographs.

The main indication for operation is preservation of facial nerve function, and the chances of recovery are remote if the nerve is completely paralysed. 
TABLE II

PETROUS PEARLY TUMOURS

\begin{tabular}{|c|c|c|c|c|c|c|c|}
\hline & Age & Sex & $\begin{array}{l}\text { Past Ear } \\
\text { Infection }\end{array}$ & Deafness & $\begin{array}{l}\text { Facial Nerve } \\
\text { Paralysis }\end{array}$ & $\begin{array}{l}\text { Post-operative } \\
\text { Recovery }\end{array}$ & $\underset{\text { (mg./100 ml.) }}{\text { C.S.F. Protein }}$ \\
\hline $\begin{array}{l}\text { 1. J.H. (R.I. No. 15391) } \\
\text { 2. R.T. (R.I. No. 23085) } \\
\text { 3. G.C. (R.I. No. 5596/43) } \\
\text { 4. R.A. (R.I. No. 120535/50) } \\
\text { 5. G.S. (R.I No. O.P.D.) } \\
\text { 6. A.H. (R.I. No. 210435) }\end{array}$ & $\begin{array}{l}42 \\
60 \\
53 \\
40 \\
54 \\
37\end{array}$ & $\begin{array}{l}\mathbf{M} \\
\mathbf{M} \\
\mathbf{M} \\
\mathbf{M} \\
\mathbf{M} \\
\mathbf{M}\end{array}$ & \begin{tabular}{|c|} 
During P.I. \\
Yes \\
Yes \\
Yes \\
No \\
Yes
\end{tabular} & $\begin{array}{l}\text { Yes } \\
\text { Yes } \\
\text { Yes } \\
\text { Yes } \\
\text { No } \\
\text { Yes }\end{array}$ & 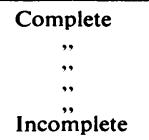 & $\begin{array}{c}\text { No } \\
\text { Partial } \\
\text { No } \\
\text { No operation } \\
\text { No operation } \\
\text { Complete paralysis }\end{array}$ & $\begin{array}{l}35 \\
30 \\
50 \\
58 \\
65\end{array}$ \\
\hline
\end{tabular}

Better results could be expected by earlier operation when only a partial paralysis exists. Four of these patients had operations for this condition, but improved facial nerve function was observed in only one case.

The origin of these tumours remains unsettled. Their relation to infection cannot be doubted, but the question arises as to cause and effect. Are they the result of middle ear or mastoid disease, or do they occur as inclusion epidermoids contributing to the otitic infection? Some writers lean towards the latter view and make a sharp distinction between these "true epidermoids" and the middle ear " cholesteatomas" that are known to be the result of infection (Bailey, 1924; Critchley and Ferguson, 1928; Jefferson and Smalley, 1938). It has been postulated that their origin is related to the development of the middle ear (Körner, 1900, cited by Rosenwasser, 1935).

Other authors are convinced that they arise as the result of infection because of their frequent association with chronic ear disease (Grant and Austin, 1950; Love and Kernohan, 1936; Rand and Reeves, 1943).

Simpson (1954) proposed that they begin as a serous effusion into which cholesterin crystals are deposited because of a high serum cholesterol level. This in turn would evoke a foreign body reaction, and later, because of this tissue response, a metaplasia of the lining cells to epidermoid elements would occur.

Diploic.-There were no examples of diploic pearly tumours in this series, but we were fortunate enough to encounter two cases on the Neurosurgical Service at the University Hospital, Ann Arbor, Michigan. Dr. Edgar Kahn has kindly permitted us to discuss them.

One was a 67-year-old woman who presented with a soft fluctuant mass in the right parietooccipital region of the scalp that she had noted for seven years. There were no symptoms other than the presence of the lesion itself, and neurological examination failed to reveal any abnormalities.

Skull radiographs revealed a large bony defect in the right parieto-occipital region (Fig. 10). Its margins were scalloped and thickened, and there was some suggestion of trabeculation, signs su华ciently characteristic to suggest the diagnosis pEoperatively.

At operation a typical pearly tumour was found which had eroded through both the inner and outer tables of the skull. It was removed, and the bofiny defect repaired with acrylium. The underlying dưpa was found to be intact and was not opened. Hètr convalescence was satisfactory.

The other example was in a 60-year-old man who
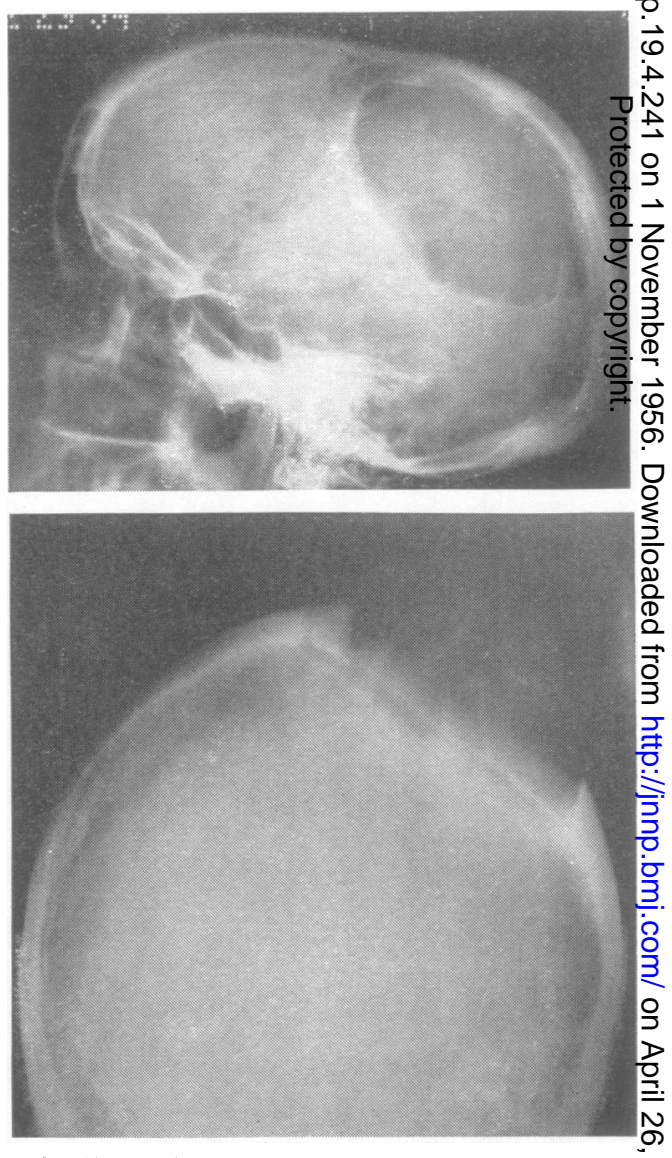

FIG. 10.-Skull radiographs showing a typical diploic pearly tum Note the smooth, thickened, bony margin. Some scallopin present along with some suggestion of trabeculation. 
had had epilepsy for 35 years. As a young man he had been struck on the vertex of the skull with a pickaxe and he began having convulsions soon thereafter. Examination revealed nothing of any significance apart from some tenderness in the right temporal region. Skull radiographs, however, revealed a circular defect in the right frontotemporal region. Again, the edges were rounded and thickened, with a suggestion of scalloping, and a large area of calcification was seen in its centre.

A pearly tumour was found at operation that had eroded both tables of the skull and had extended through the dura to insinuate itself in the depths of the Sylvian fissure. As far as could be determined, the tumour was entirely removed and an acrylic cranioplasty was performed. There were no untoward events in his recovery, but unfortunately the epilepsy continues.

Histologically, both tumours were epidermoids.

Almost all of the examples of these intradiploic tumours recorded in the literature have been epidermoids (King, 1939; Mahoney, 1936; Rand and Reeves, 1943), although occasionally dermoids have been encountered (Schoen, 1939). Because of their slow growth, they may become tremendous and cause marked distortion of the underlying brain without producing much in the way of neurological signs (Horrax, Yorshis, and Lavine, 1935; King, 1939). The characteristic radiological changes are generally believed to be diagnostic.

Suprasellar.-Pearly tumours in the suprasellar region usually present as chiasmal syndromes of long duration. As a rule, endocrine changes are not evident (Findeisen and Tönnis, 1937; Floris and Castorina, 1950; Olivecrona, 1932; Rand and Reeves, 1943).

There are two examples in this series, both of them in women. One was 25 years of age, with visual symptoms for at least 11 years. She was completely blind in the left eye and had a temporal hemianopia in the right. There was optic atrophy bilaterally. She was obese, but there were no endocrine abnormalities.

The other was a 36-year-old woman, with visual symptoms for four years. She had a bitemporal hemianopia, with diminished visual acuity bilaterally. Primary optic atrophy was present in both eyes. Again no endocrine changes were found.

In both patients the cerebrospinal fluid protein was normal.

Skull radiographs revealed flattening of the dorsum sellae and posterior clinoid processes in one case. In the other, the sella turcica and the optic foramina were normal, but arteriograms demonstrated a suprasellar mass.

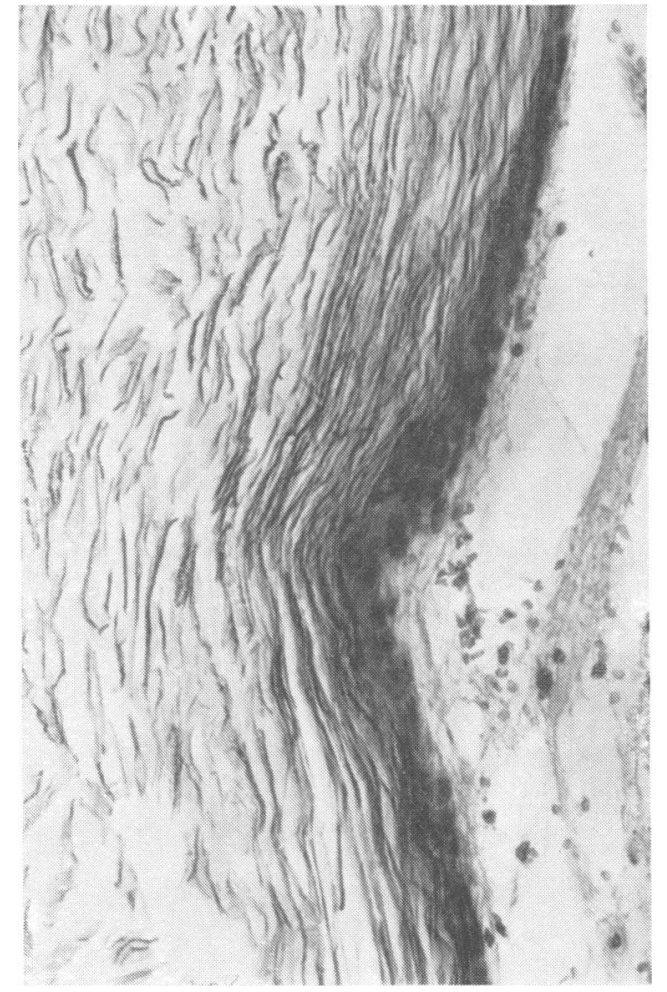

FIG. 11.-Microscopic section of the capsule of a suprasellar pearly tumour. There is a layer of stratified squamous epithelium without any trace of dermal elements. Inside the epidermal layer there are abundant amounts of laminated debris that make up the bulk of the tumour. (Haematoxylin and eosin $\times 268$.)

At operation typical pearly tumours were found. In each instance the capsule was extremely thin and intimately associated with the various structures in this region, especially the optic nerves and internal carotid arteries. The interior of the tumours was removed and that part of the wall that would come away freely was excised. Total removal was not attempted, for fear of further damaging the optic nerves.

Unfortunately, no traces of the capsule could be found in one patient, although there was abundant amorphous flaky material in the histological sections. Sections of the capsule from the other patient revealed a layer of stratified squamous epithelium without any trace of dermal elements (Fig. 11).

In the first patient, vision improved considerably in the right eye and the temporal hemianopia disappeared. The left eye remained blind. She continues to do well from this standpoint five years post-operatively.

The other patient also improved, with a filling out of both visual fields, but recurrence may have taken place after seven years. 
In 1932 Olivecrona presented two patients with similar lesions. In both cases the chiasmal syndrome predominated, with optic atrophy and visual field changes the main abnormal findings. Endocrine function was unimpaired.

He graphically described his operative findings, emphasizing the adherence cf the capsule to vital structures, and advised against any attempt at its total removal. There is general agreement on this point (Findeisen and Tönnis, 1937; Rand and Reeves, 1943).

$\mathrm{He}$ mentioned radiological changes in the sellar region not encountered in the present series. These consisted of widening of one or both optic foramina and enlargement of the sulcus chiasmaticus. The sella turcica itself was intact. Findeisen and Tönnis (1937), on the other hand, described an example of sellar erosion in a suprasellar epidermoid. Suprasellar calcification in these tumours has also been reported (Floris and Castorina, 1950).

Endocrine abnormalities have been known to occur in association with suprasellar epidermoids. David, Lacroix, Thierry, and Brun (1936) described infantilism and undescended testes in an 11-year-old boy. Other examples have been recorded by de Martel and Guillaume (1938) and by Paleari (1939). It would appear from these reports that the " suprasellar epidermoid" was clearly distinguished from the more common Rathké pouch tumour.

Intracerebral.-Certain points about the intracerebral pearly tumours tend to differentiate them from other intracranial neoplasms. Epilepsy is often a presenting complaint and may exist as the only of increased intracranial pressure are by no means a constant finding, and the cerebrospinal fluid

There were seven patients in this series with symptom for years before the onset of others. Signs protein is usually normal.

lesions of this nature (Table III). Epilepsy feature $\$$ in the history of four of them. In one (Case 7) was the only complaint. In three others (Cases 5 , and 6) it constituted the initial symptom and on terminally became associated with other complaints. A fifth patient (Case 4) had peculiar attacks o drowsiness, unassociated with convulsions, late i the illness. Epilepsy is known to have occurred if $41 \%$ of 138 cases of cerebral epidermoids and dermoids recorded in the literature.

Although most of the patients in this group ha $\Phi$ signs indicating the presence of an intracrania tumour, four of them had normal fundi, and indee only $50 \%$ of 212 intracranial epidermoids an 1 dermoids found in the literature were noted to haves papilloedema. One of our patients (Case 5), with a 10-year-history of epilepsy, had no abnormal neurological findings. Increased cerebrospinal fluid pressure incited further investigations which reveale a huge epidermoid, $8-10 \mathrm{~cm}$. in diameter, in the temporo-parietal region.

Pre-operative cerebrospinal fluid studies wer. available in five cases. In three of them the proteif was well within normal limits. In the other two was only slightly elevated. Among 58 cases in ${ }^{\text {the }}$ literature in which the spinal fluid was examing there were only eight in which the protein confent was increased, an incidence of $14 \%$.

All of these patients were operated upon, \&n removal was thought to have been complete in of them, although, as will appear later, it is offen difficult to be certain that all portions of the capstite have been removed. One patient (Case 4) died two years post-operatively of unknown cause. Afteng such a short interval it is unlikely to have been recurrence. On the other hand, another patient (Case 2) died of recurrence 13 years after operation There are no signs of recurrence in the others who

TABLE III

INTRACEREBRAL PEARLY TUMOURS

\begin{tabular}{|c|c|c|c|c|c|c|c|c|c|c|}
\hline & Age & Sex & $\begin{array}{c}\text { Duration } \\
\text { of } \\
\text { Symptoms } \\
\text { (yr.) }\end{array}$ & Epilepsy & $\begin{array}{c}\text { Papill- } \\
\text { oedema }\end{array}$ & $\begin{array}{l}\text { C.S.F. } \\
\text { Protein } \\
\text { (mg./ } \\
100 \mathrm{ml} .)\end{array}$ & $\begin{array}{l}\text { Post- } \\
\text { operative } \\
\text { Pleo- } \\
\text { cytosis }\end{array}$ & $\begin{array}{l}\text { Estimated } \\
\text { Removal }\end{array}$ & $\begin{array}{l}\text { Recur- } \\
\text { rence }\end{array}$ & $\begin{array}{l}\text { Years } \\
\text { Followed }\end{array}$ \\
\hline $\begin{array}{l}\text { 1. G.M. (London Hospital) } \\
\text { 2. W.F. (St. Hugh's Hospital, } \\
\text { Oxford) }\end{array}$ & $\begin{array}{l}49 \\
29\end{array}$ & $\begin{array}{l}\mathbf{F} \\
\mathbf{M}\end{array}$ & $\begin{array}{c}8 \\
3 \mathrm{mth}\end{array}$ & $\begin{array}{l}\text { Yes } \\
\text { No }\end{array}$ & $\begin{array}{l}\text { No } \\
\text { Yes }\end{array}$ & $\begin{array}{l}30 \\
35\end{array}$ & $\begin{array}{l}\text { No } \\
\text { Yes* }\end{array}$ & $\begin{array}{l}\text { Complete } \\
\text { Incom- } \\
\text { plete }\end{array}$ & $\begin{array}{l}\text { No } \\
\text { Yes }\end{array}$ & $\begin{array}{l}\text { Died of } \\
\text { currence } \\
\text { 13 years pos }\end{array}$ \\
\hline 3. E.E. (St. Hugh's Hospital, & 24 & $\mathbf{F}$ & $6 \mathrm{mth}$. & No & Yes & 65 & & & No & \\
\hline 4. D.A. (R.I. No. 51993/46) & 30 & $\mathbf{F}$ & 2 & Yes & No & 一 & Yest & Complete & No & $\begin{array}{l}\text { Died } 2 \text { years } \\
\text { post- } \\
\text { operatively }\end{array}$ \\
\hline $\begin{array}{l}\text { 5. W.H. (R.I. No. 63934/46) } \\
\text { 6. L.H. (R.I. No. 108193/49) }\end{array}$ & $\begin{array}{l}31 \\
28\end{array}$ & $\underset{\mathbf{F}}{\mathbf{M}}$ & $\begin{array}{l}10 \\
10\end{array}$ & $\begin{array}{l}\text { Yes } \\
\text { Yes }\end{array}$ & $\begin{array}{l}\text { No } \\
\text { Yes }\end{array}$ & $\frac{20}{-}$ & $\begin{array}{l}\text { Yes } \\
\text { No }\end{array}$ & $\begin{array}{l}\text { Complete } \\
\text { Incom- }\end{array}$ & $\begin{array}{l}\text { No } \\
\text { No }\end{array}$ & $\begin{array}{r}8 \\
6\end{array}$ \\
\hline 7. D.W. (R.I. No. 197549) & 29 & $\mathbf{M}$ & 8 & Yes & Yes & 60 & No & $\begin{array}{l}\text { Incom- } \\
\text { plete }\end{array}$ & No & 1 \\
\hline
\end{tabular}




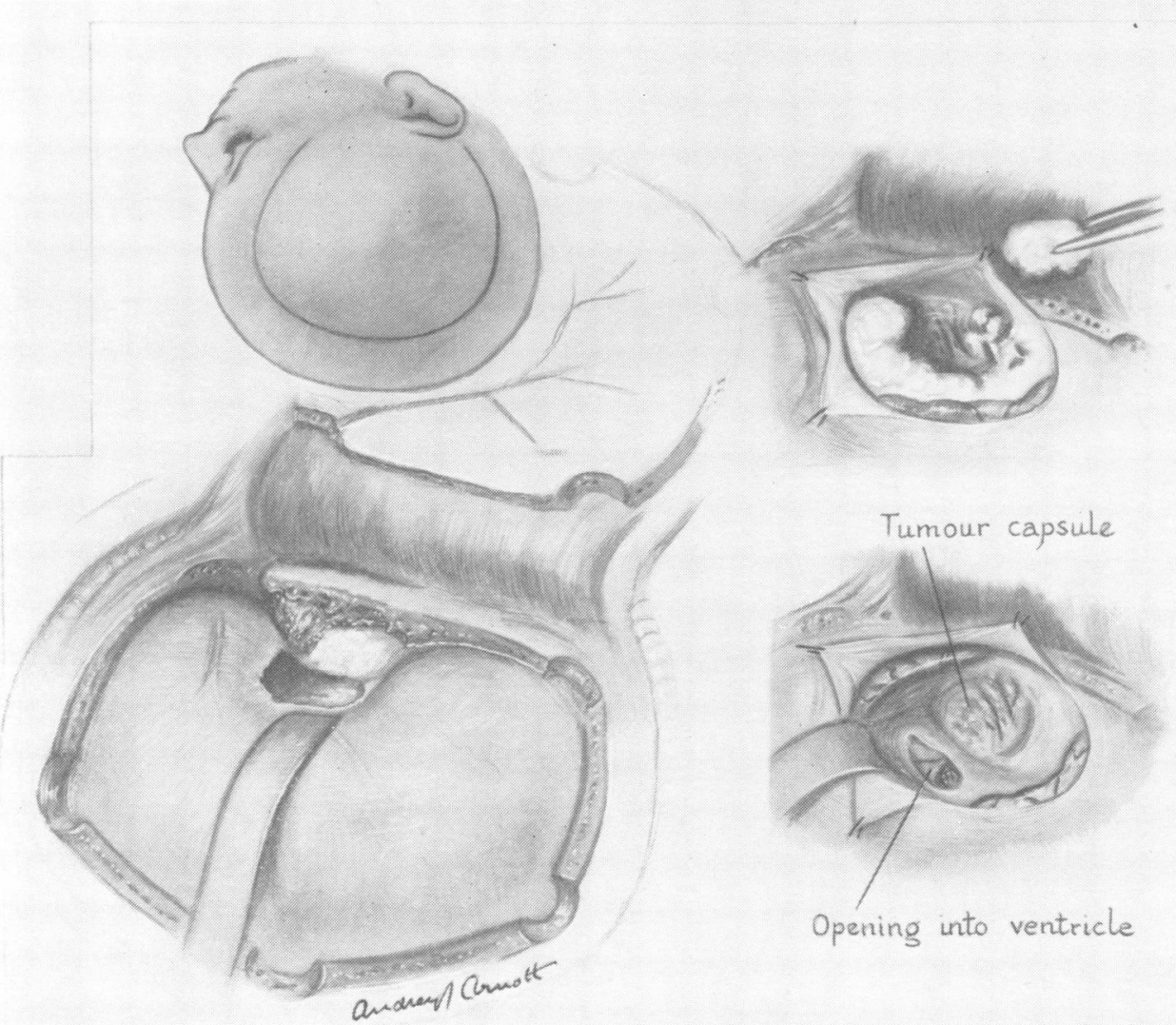

FIG. 12.-Operative drawing of an intracerebral pearly tumour (Case 4). It apparently arose from the temporal bone, penetrated the dura, and eventually extended into the temporal horn of the lateral ventricle.

have been followed for an average period of nine years. Histologically, all of these tumours were epidermoids.

In three of these patients the post-operative course was complicated by a persistent cerebrospinal fluid pleocytosis which prolonged their convalescence considerably.

The most characteristic feature of these lesions is their ventriculographic appearance. This is by virtue of their almost invariable relation to the subarachnoid space or lateral ventricles. In all of the patients in this series the tumour lay in direct relation to some part of the lateral ventricles. It was primarily intraventricular in five cases. In one case it seemed to extend into the ventricle from the subarachnoid space, and in another (Case 4) it arose from the temporal bone and extended into the temporal horn (Fig. 12).

Pre-operative air studies were performed in five patients and in each instance radiography revealed characteristic findings (Figs. 13 and 14). There are the usual signs of a space-occupying mass, but in addition scattered collections of air may be seen dispersed throughout the tumour, though on the whole more concentrated about its periphery. This cauliflower- or sponge-like appearance represents a lacework of communicating channels in the irregular grooves and clefts over the surface of the tumour, which may be thrown into deep folds.

These characteristics have been described previously and are generally agreed to be diagnostic (Childe and Young, 1947; Dyke and Davidoff, 1937; Weinberger, 1938).

Cerebello-pontine Angle.-The cerebello-pontine angle is not an unusual location for the epidermoid type of pearly tumours which must be differentiated from the more common acoustic neurinomas and meningiomas.

Three examples were found in this series (Table IV). 

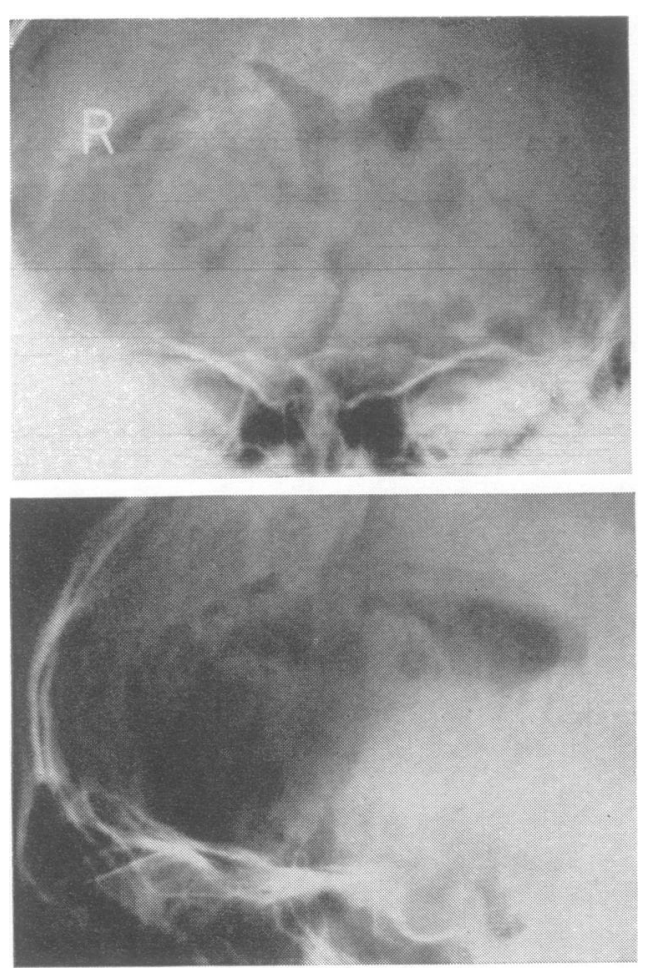

Fig. 13.-Encephalogram (Case 7). Pearly tumour in the right frontal region. (For description see text.)

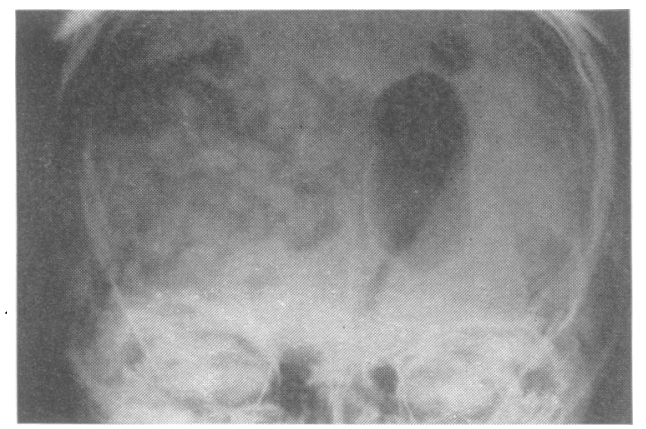

Fig. 14.-Ventriculogram (Case 5). Pearly tumour right frontotemporal region. (For description see text.)
All had findings typical of tumours in this region such as ataxia, with ipsilateral fifth, seventh, an eighth nerve involvement. In addition, one patie (Case 2) had a contralateral homonymous hemianopia which was found to result from an extensiog of the tumour through the incisura compressing the posterior cerebral artery. None of them presented with symptoms of trigeminal neuralgia, which has been described in other series (Gonzalez Revilla 1947; Olivecrona, 1949). There was a long histof of gradually increasing disability in all thre. Papilloedema was present in two patients. In a of them the cerebrospinal fluid protein was normas Radiographs of the petrous bones were also norma in each case.

At operation typical pearly tumours were found: Total removal was thought to have been accomiplished in only one case, portions of the capsutect having been left behind in the other two. All of the tumours were epidermoids (Fig. 15).

One patient died two months after operation of an aseptic meningitis and bronchopneumoniạ Another has increasing ataxia eight years post operatively which may represent incipient recurrefce The third patient, whose tumour was probåb completely removed, is well six years postoperatively.

A normal cerebrospinal fluid protein concen tion seems to be a characteristic of pearly tumg1 in this region. This was true in all of the case this group. Of the 49 examples of cerebello-pondre angle epidermoids found in the literature, the were 13 cases in which the cerebrospinal flum findings were recorded. In 11 of these the protein was within normal limits. Findeisen and Tönns

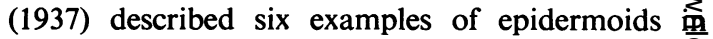
this location and remarked on the normal spin il fluid findings in five of them.

Although all three of the patients in this groư were virtually totally deaf, with absent calor responses on the involved side, other examples are recorded in which eighth nerve involvement was not evident. Olivecrona (1949) found that in five out of seven of his patients with cerebello-pontine ange " cholesteatomas" eighth nerve function was normat.

TABLE IV

CEREBELLO-PONTINE ANGLE PEARLY TUMOURS

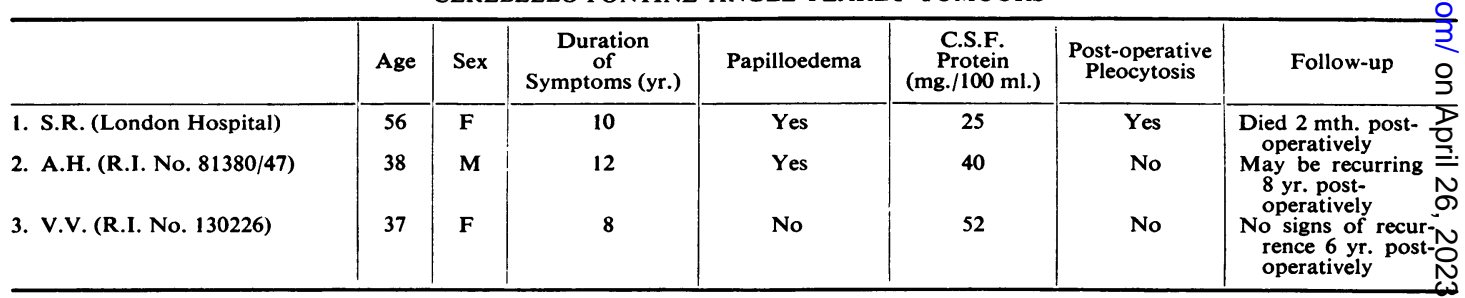


Gonzalez Revilla (1948) found normal hearing in 10 out of 13 patients with this condition. In nine of them labyrinthine function was also unimpaired. Lewis and Echols (1951) described a patient whose hearing improved following removal of a tumour of this nature.

In patients presenting with a cerebello-pontine angle syndrome, a normal protein in the cerebrospinal fluid suggests the presence of a pearly tumour, although this sometimes occurs in meningiomas and very rarely in acoustic tumours. An intact eighth nerve on the affected side may be further evidence for this diagnosis.

Cerebellar.-Pearly tumours arising in the region of the cerebellum tend to lie in the midline, occupying the vermis and fourth ventricle. Histologically, the majority of these are dermoids and, as such, are frequently associated with other congenital anomalies (Logue and Till, 1952; Matson and Ingraham, 1951; Peyton and Baker, 1942).

Eight patients in this series had pearly tumours in this region (Table V). All of them lay in the midline, occupying the vermis or fourth ventricle. Only two of these lesions were epidermoids; the rest were dermoids.

Three of the patients with dermoids also had dermoids of the scalp, together with dermal sinuses. In addition, multiple fusion defects were noted in radiographs of the vertebral column of one patient.

In only three cases was papilloedema evident. Cerebrospinal fluid determinations were available in six cases, although in one they were complicated by the presence of meningitis. The protein level was elevated in three instances.

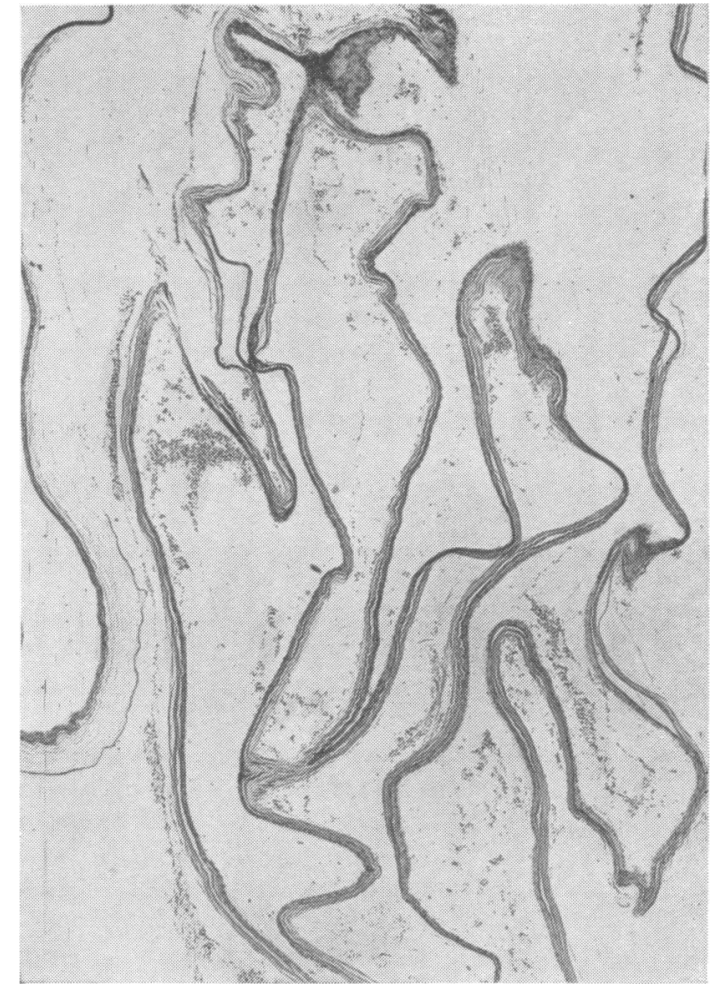

FIG. 15.-Microscopic section showing the tumour capsule in Case 3 of the cerebello-pontine angle group. The epidermal layer is extremely thin and in places is only one or two cells in thickness. No dermal elements are present. (Haematoxylin and eosin $\times 40$.)

All of these patients had operations. Removal was believed to have been total in seven cases. Three

TABLE V

CEREBELLAR PEARLY TUMOURS

\begin{tabular}{|c|c|c|c|c|c|c|c|c|c|c|}
\hline & Age & Sex & $\begin{array}{c}\text { Other } \\
\text { Anomalies }\end{array}$ & $\begin{array}{l}\text { Papill- } \\
\text { oedema }\end{array}$ & $\begin{array}{c}\text { C.S.F. } \\
\text { Protein } \\
(\mathrm{mg} . / 100 \mathrm{ml} .)\end{array}$ & $\begin{array}{l}\text { Estimated } \\
\text { Removal }\end{array}$ & Type & $\begin{array}{l}\text { C.S.F. } \\
\text { Pleo- } \\
\text { cytosis }\end{array}$ & $\begin{array}{l}\text { Recur- } \\
\text { rence }\end{array}$ & $\begin{array}{l}\text { Years } \\
\text { Followed }\end{array}$ \\
\hline 1. J.S. & 6 & $\mathbf{F}$ & No & Yes & - & Complete & Dermoid & No & No & 22 \\
\hline $\begin{array}{l}\text { 2. E.S. (R.I. No. 7560) } \\
\text { 3. E.D. } \\
\text { (R.I. No. 97680/48) }\end{array}$ & $\begin{array}{l}32 \\
55\end{array}$ & $\begin{array}{l}\mathbf{M} \\
\mathbf{F}\end{array}$ & $\begin{array}{l}\text { No } \\
\text { No }\end{array}$ & $\begin{array}{l}\text { Yes } \\
\text { No }\end{array}$ & $\begin{array}{l}45 \\
65\end{array}$ & $\begin{array}{l}\text { Complete } \\
\text { Complete }\end{array}$ & $\begin{array}{l}\text { Epidermoid } \\
\text { Dermoid }\end{array}$ & $\begin{array}{l}\text { Yes } \\
\text { Yes* }\end{array}$ & No & $\begin{array}{l}16 \\
\text { Died } 5 \text { weeks } \\
\text { post- } \\
\text { oneratively }\end{array}$ \\
\hline $\begin{array}{l}\text { 4. T.C. } \\
\text { (R.I. No. 125415/50) }\end{array}$ & 18 & $\mathbf{F}$ & No & No & - & Complete & Dermoid & Yes & 一 & $\begin{array}{l}\text { Died } 24 \text { hr. post- } \\
\text { operatively }\end{array}$ \\
\hline $\begin{array}{l}\text { 5. E.C. } \\
\text { (R.I. No. 133140) }\end{array}$ & 39 & $\mathbf{F}$ & No & No & 55 & Complete & Epidermoid & Yes & No & 5 \\
\hline $\begin{array}{l}\text { 6. C.D. } \\
\text { (R.I. No. 153722) }\end{array}$ & 3 & $\mathbf{M}$ & $\begin{array}{l}\text { Dermal sinus ; } \\
\text { dermoid scalp } \\
\text { excised } 6 \mathrm{mth} \text {. } \\
\text { before }\end{array}$ & Yes & 80 & Complete & Dermoid & $\begin{array}{l}\text { Admitted } \\
\text { with } \\
\text { menin- } \\
\text { gitis } \dagger\end{array}$ & - & $\begin{array}{l}\text { Died } 4 \text { weeks } \\
\text { post- } \\
\text { operatively }\end{array}$ \\
\hline 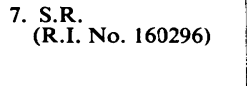 & 5 & $\mathbf{F}$ & $\begin{array}{l}\text { Dermal sinus ; } \\
\text { dermoid scalp, } \\
\text { fusion defects } \\
\text { spine }\end{array}$ & No & 125 & Complete & Dermoid & Yes & No & 4 \\
\hline 8 C.N. (R.I.) & 20 & $\mathbf{M}$ & $\begin{array}{l}\text { Dermoid scalp } \\
\text { and dermal si- } \\
\text { nus excised at } \\
5 \text { years of age }\end{array}$ & No & 70 & $\begin{array}{l}\text { Incom- } \\
\text { plete }\end{array}$ & Dermoid & Yesł & No & 4 \\
\hline
\end{tabular}

* Developed a Gram-achromobacter meningitis.

$\dagger$ Admitted with meningitis.

‡ Transient episode of meningismus three years post-operatively; cultures all sterile. 

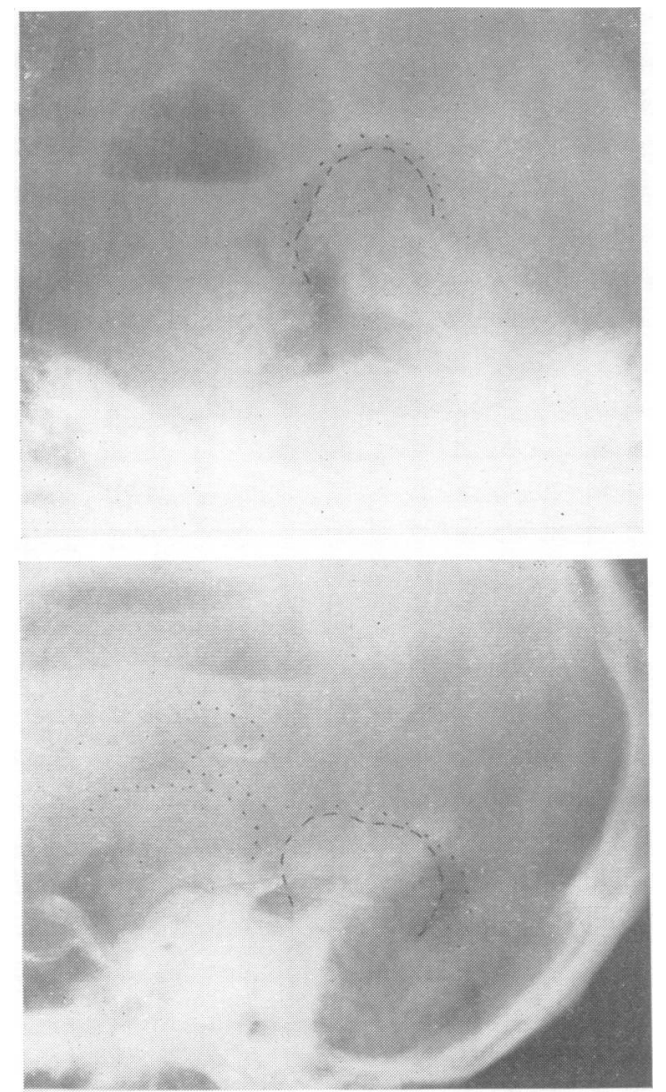

Fig. 16.-Encephalogram in a cerebellar pearly tumour (Case 5). The tumour can be seen projecting into a dilated fourth ventricle. (Frorn Sheldon, Wickbom, and Pennybacker, 1953, by permission of the publishers.)

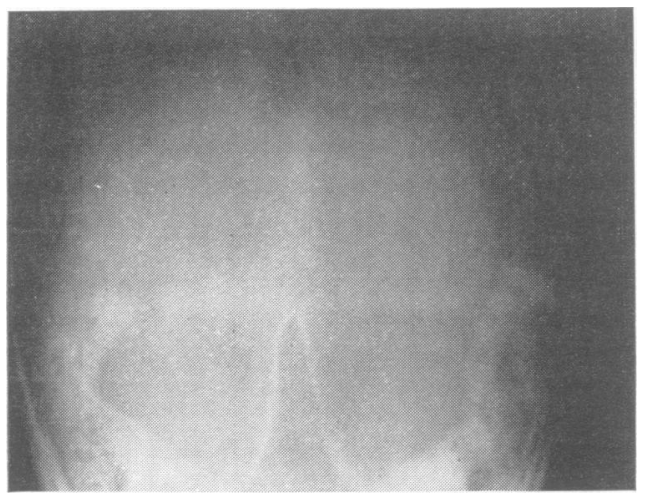

FIG. 17.-Occipital skull radiograph in a cerebellar dermoid (Case 6) showing the linear bony defect lying in the midline. deaths occurred in the immediate post-operative period. There have been no signs of recurrence i $\overline{\overline{6}}$ those surviving.

Six patients had a prolonged cerebrospinal flư⿱ pleocytosis post-operatively.

Clinically, these patients sometimes present as straightforward cerebellar tumours; on the othe⿳亠丷厂 hand, they may present a very bizarre clinical picture

One patient (Case 3) had signs and symptom suggesting a spinal cord tumour, but she also had seventh nerve palsy. At operation a dermoid wo found involving the upper cervical cord and extene. ing through the foramen magnum to lodge in th vermis and fourth ventricle. During the remova of this tumour some of its fragments spilled into the subarachnoid space. She developed a cerebrospinat fluid pleocytosis, but all the cultures remained sterile for one month. She then developed a Grame negative Achromobacter meningitis and died fou days later.

Another patient (Case 4) was thought to have disseminated sclerosis. She had complained of difficulty in swallowing and mild unsteadiness for two years intermittently. Ten days before admisgrot her condition worsened, and she was admitited critically ill. In the absence of signs of incres intracranial pressure an encephalogram was Berz formed, revealing a large posterior fossa tumæu? After this her condition deteriorated to suchôa extent that immediate exploration was deemeg necessary. At operation a large dermoid was foựix, occupying the vermis and fourth ventricle. Remô요 of this tumour was not particularly difficult, bọ she remained critically ill and died 24 hours post operatively.

Case 5 presented as a cerebello-pontine ang syndrome, with ataxia and deafness associated wi a fifth and seventh nerve involvement. An enceph $\overline{8}$ logram was performed, however, which revealed 7 large tumour in the fourth ventricle that had a appearance highly suggestive of a pearly tumour (Fig. 16). At operation an epidermoid was found, occupying the fourth ventricle and extending through the foramen of Luschka. This was removed, and she remains fairly well five years after operation.

Of special importance are patients in this grou with dermal sinuses, because of the risk of meniingitis to which attention was called by Matson am Ingraham (1951). One (Case 6) was a 3-year-ogुd child who had a small cyst in the occipital region that drained occasionally, and for two years he hat had recurrent bouts of meningitis. Six montre before admission this cyst had been excised. was admitted suffering from a $B$. coli and alpha haemolytic streptococcus meningitis which prova् 


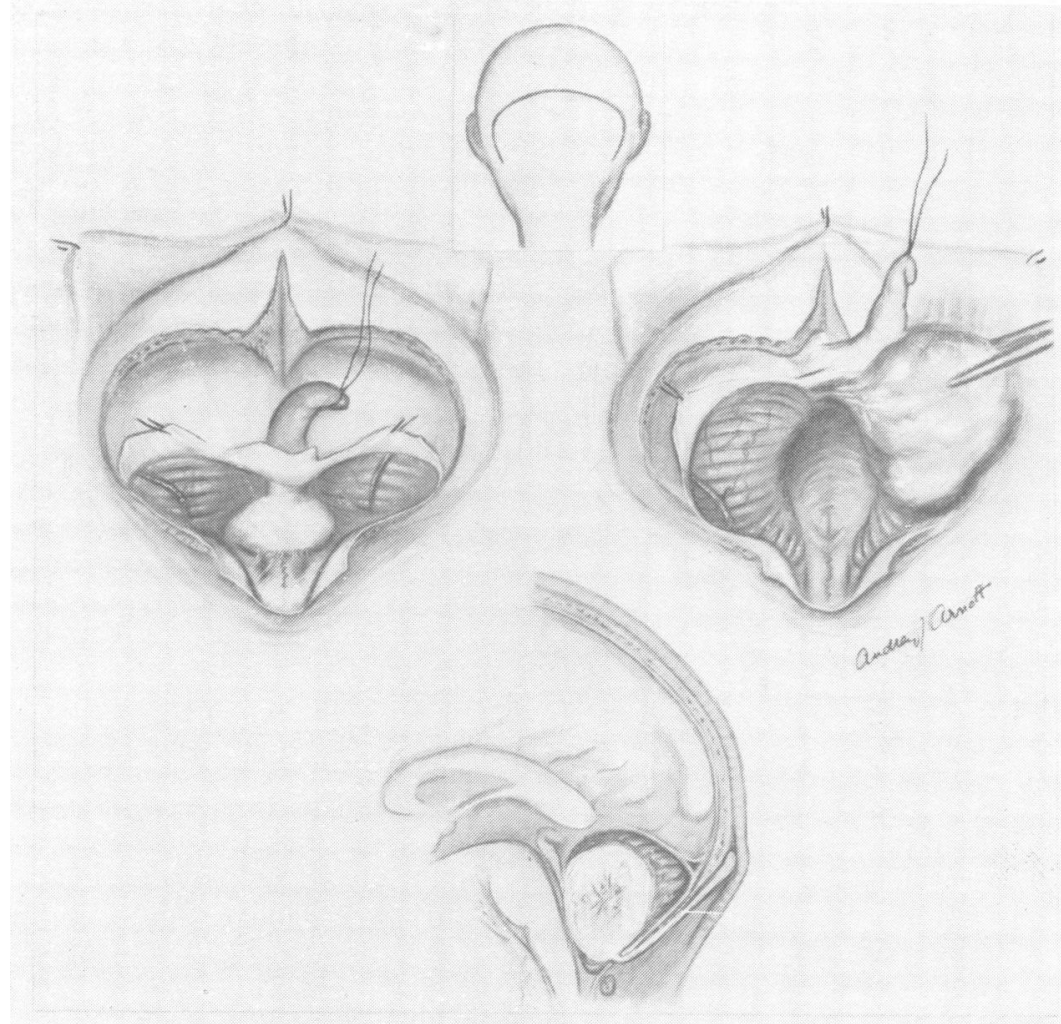

FIG. 18.-Operative drawing (Case 6 of the cerebellar group) showing the relations of the dermal sinus to the bony groove and to the cerebellar dermoid. (For description, see text.)

refractory to treatment. In addition to meningeal signs, his head was enlarged and he had bilateral papilloedema and bilateral sixth nerve palsies. There were no cerebellar signs. Skull radiographs revealed a midline groove in the occipital bone through which the deep attachments of the scalp dermoid had presumably extended (Fig. 17).

After three days of ventricular drainage, cerebellar exploration was carried out (Fig. 18). The sinus was identified, embedded in a groove in the occipital bone. No complete bony defect was found. It pierced the dura at the foramen magnum and, on exposing the cerebellum, was seen to enter a pinkishwhite tumour occupying the greater part of the vermis and displacing both cerebellar hemispheres laterally. The tumour contained typical caseous material and a few hairs. It also contained pus, and the surrounding area was obviously infected.

The histological sections revealed a typical dermoid tumour with infiltration of the dermal layer by inflammatory cells (Fig. 19).

The child was given large doses of antibiotics after removal of the tumour, but he remained critically ill and died one month post-operatively.

Of the remaining patients with dermal sinuses one, a 5-year-old girl (Case 7), presented with a draining occipital sinus and signs of increased intracranial pressure. She had never had meningitis.

Skull radiographs revealed the same findings as noted before, a linear groove in the occipital bone (Fig. 20). In addition, there were multiple fusion defects throughout the whole of the vertebral column.

At operation a dermal sinus was found extending into a large mid-cerebellar dermoid. Removal was without event, and she remains well four years later.

The third patient, a 20-year-old man (Case 8), had had a scalp dermoid and dermal sinus excised at 5 years of age and a large posterior fossa dermoid subtotally removed three years before. $\mathrm{He}$ was admitted with a cerebrospinal fluid pleocytosis, presumably related to the remaining tumour, but this subsided with chemotherapy and further exploration was not called for. 


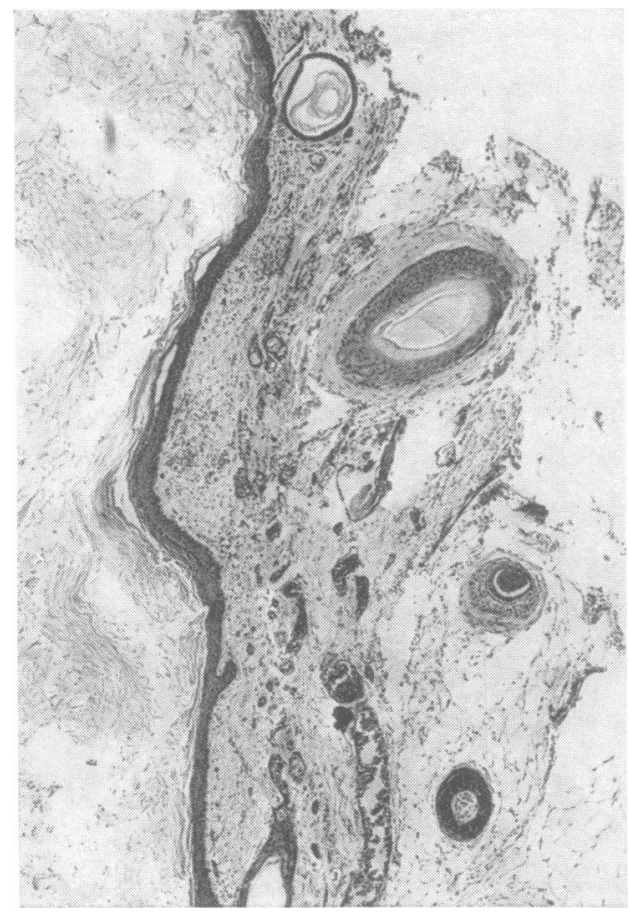

FIG. 19.- Histological section of the tumour capsule in a cerebellar dermoid (Case 6). In addition to the epidermal layer, a dermal layer is also present containing hair follicles, fat, and connective tissue. Infiltration by inflammatory processes can also be seen. (Haematoxylin and eosin $\times 46$.)

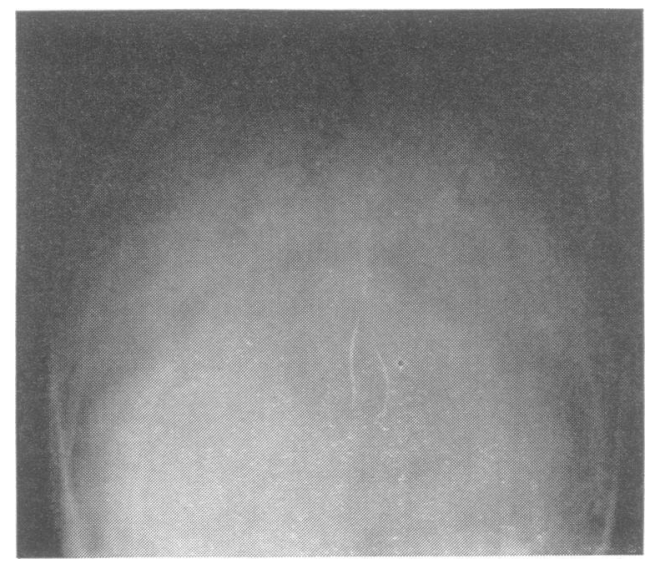

FIG. 20.-Occipital skull radiograph (Case 7 of the cerebellar group) showing another example of this linear groove. Note the separation of the sagittal suture.
The main considerations in respect to the posterie fossa pearly tumours would seem to be twofold.

In the first place, early operation seems indicate once the diagnosis of a posterior fossa tumour h been made. Two of the three post-operative deaths in this group (Cases 3 and 4) occurred in patien's who had had symptoms for seven years and tw years respectively. Total removal is often possib without undue hazard if the tumour has not becontre too extensive and if the patient's physical state has not been overwhelmed by the attendant neurof logical deficit.

Secondly, when patients present with meningit: of unexplained origin a careful search should made for a congenital dermal sinus in the occipita region (or over the entire vertebral column, for thầt matter). These structures often extend epi- क्ष sub-durally, where they may end as a blind pouch or they may terminate in a dermoid. If they a $\overrightarrow{c o}$ patent, an obvious entrance for infection exist? Occipital skull radiographs may also help demonstrating a small midline bony defect or groove. Once the infection has been controlled, the sinus, together with its deep extension, can be remove्ç without undue risk.

On the other hand, if these sinuses are discovered in patients without a history of meningitis, 앨. should be excised to prevent such an occurreftce even in the absence of neurological signs. The points have been stressed by Matson and Ingra $8 a$ in

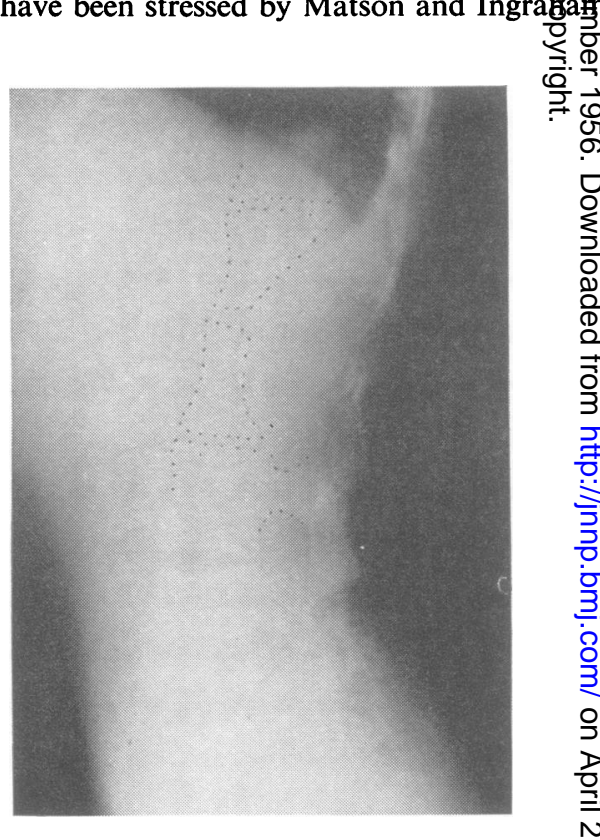

FIG. 21.-Spine radiograph (Case 4 of the intraspinal group). The erosion of the vertebral bodies is extensive. Note the thickengd bony margins. 


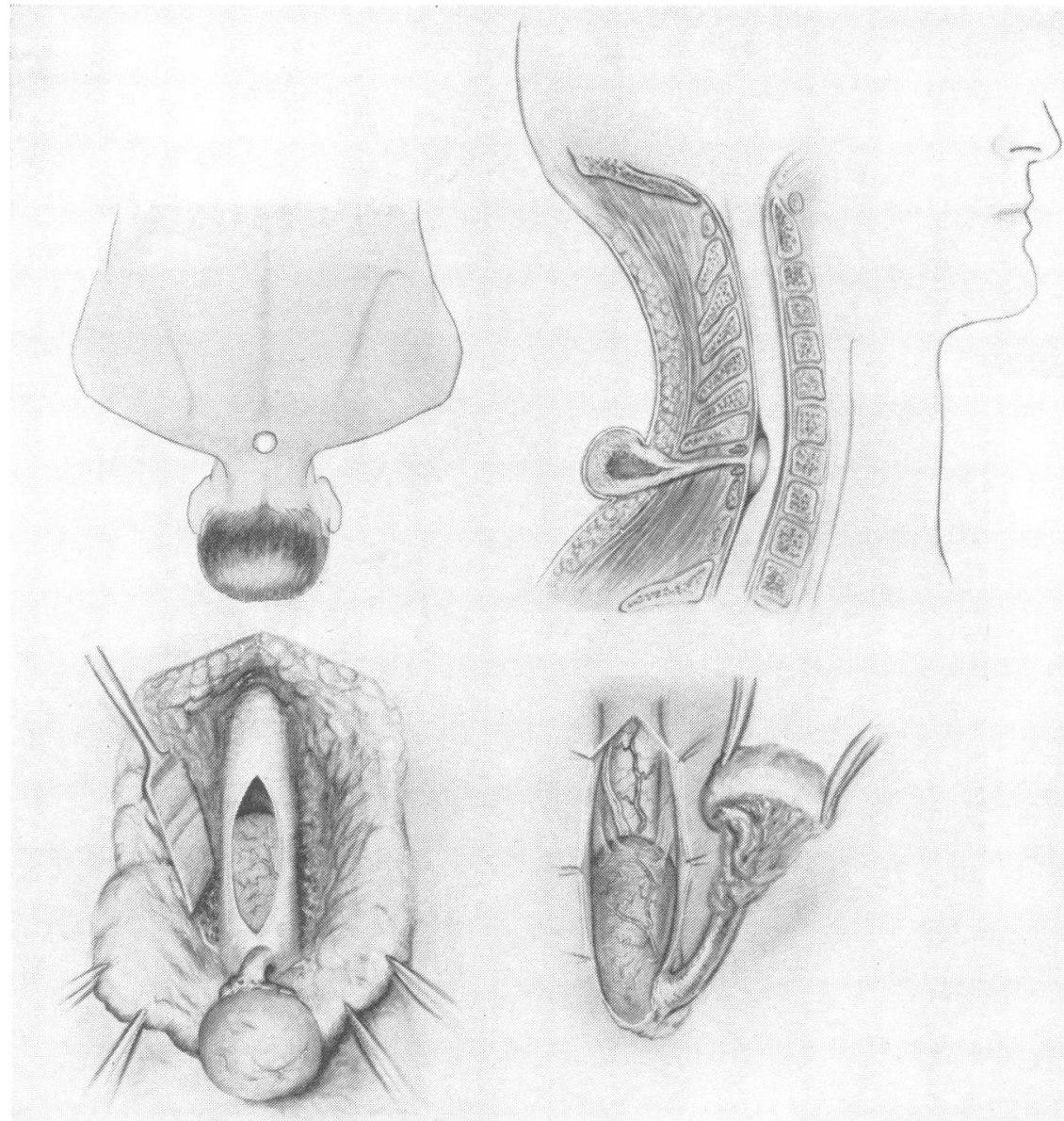

FIG. 22.-Drawing showing the relations of the tumour in Case 2 of the intraspinal group. The tumour was entirely extramedullary and was connected to a cutaneous dermoid through a sinus that extended through a bifid first thoracic vertebra.

(1951). They presented 10 patients who had congenital dermal sinuses with extensions into the posterior fossa. Meningitis was a primary feature in five of their cases. Two others had cerebellar abscesses, and one had osteomyelitis. Logue and Till (1952), in discussing the posterior fossa dermoids, described three cases having intradural dermoids with complete sinuses. Two of these patients had frank meningitis, and the third developed meningitis after excision of the sinus.

Intraspinal.-Although pearly tumours have been found at all levels of the spinal canal, they are considerably more common in its lower portion. In 1941 List collected all of the reported cases and found that $65 \%$ of these lesions were located below the twelfth dorsal vertebra. Dermoids are slightly more common in this location and, as in the occipital region, are frequently associated with other congenital anomalies, notably dermal sinuses. Sachs and Horrax (1949) reviewed this subject and found 61 cases of intraspinal dermoids and epidermoids in the literature. Of these at least 36 cases were dermoids. Of the 14 tumours associated with dermal sinuses, only one was an epidermoid. All the rest were dermoids.

Typically, either type may present as a cauda equina tumour, often becoming enormous and completely filling the spinal canal in that region. Spine radiographs may show widening of the interpeduncular space, or erosion of the pedicles themselves. Lateral views often show erosion of the posterior surfaces of the bodies (Fig. 21).

Seven patients in this series had intraspinal pearly tumours (Table VI). In all instances the tumour lay 
intradurally. It was extramedullary in two cases (Cases 1 and 3) and entirely intramedullary in two others (Cases 2 and 5). In the remaining three patients the bulk of the tumour mass lay enmeshed in the cauda equina, but its superior portion extended into the conus medullaris to become more or less continuous with it.

Histologically, there were two epidermoids in this group. The others were dermoids, three of which were associated with other anomalies, such as dermal sinus and spina bifida.

The protein content of the spinal fluid was not invariably elevated in these cases, although higher determinations were found in the intraspinal tumours compared with those located elsewhere. This was also true in other reported series and may be related to the degree and duration of spinal block.

When these tumours are intricately involved in the cauda equina, or when they invade the spinal cord itself, complete removal may be impossible without damaging these structures. They tend to recur extremely slowly, in spite of their confined location. Although operative removal was known to have been incomplete in four patients, there h/oss been known recurrence in only one instance (Case \%) four years, and again five years, after the first operation. There have been no signs of recurrenge in any of the others followed for an average of eight years.

As mentioned before, three patients had spingl dermoids in association with other congeniml abnormalities. Two of these had dermal sinuses. In one, a 40-year-old man (Case 3), it began in $\overrightarrow{\mathbf{F}^{a}}$ cutaneous mass and extended into the intradufal space through a spina bifida at the first thoragc vertebra. It terminated in a dermoid which $18 \mathrm{fy}$ over the posterior surface of the spinal cord (Fig. 2Z). This tumour lay entirely extramedullary and was believed to have been totally removed.

The other patient, an infant (Case 7), had a smat cutaneous sinus in the upper sacral region that extended intradurally through a bifid second sackipl vertebra into a large cauda equina dermoid. He presented as a staphylococcus aureus meningit度. Histological sections of this growth revealed it to be a dermoid, obviously infected, with a marke्d

Table VI

SPINAL PEARLY TUMOURS

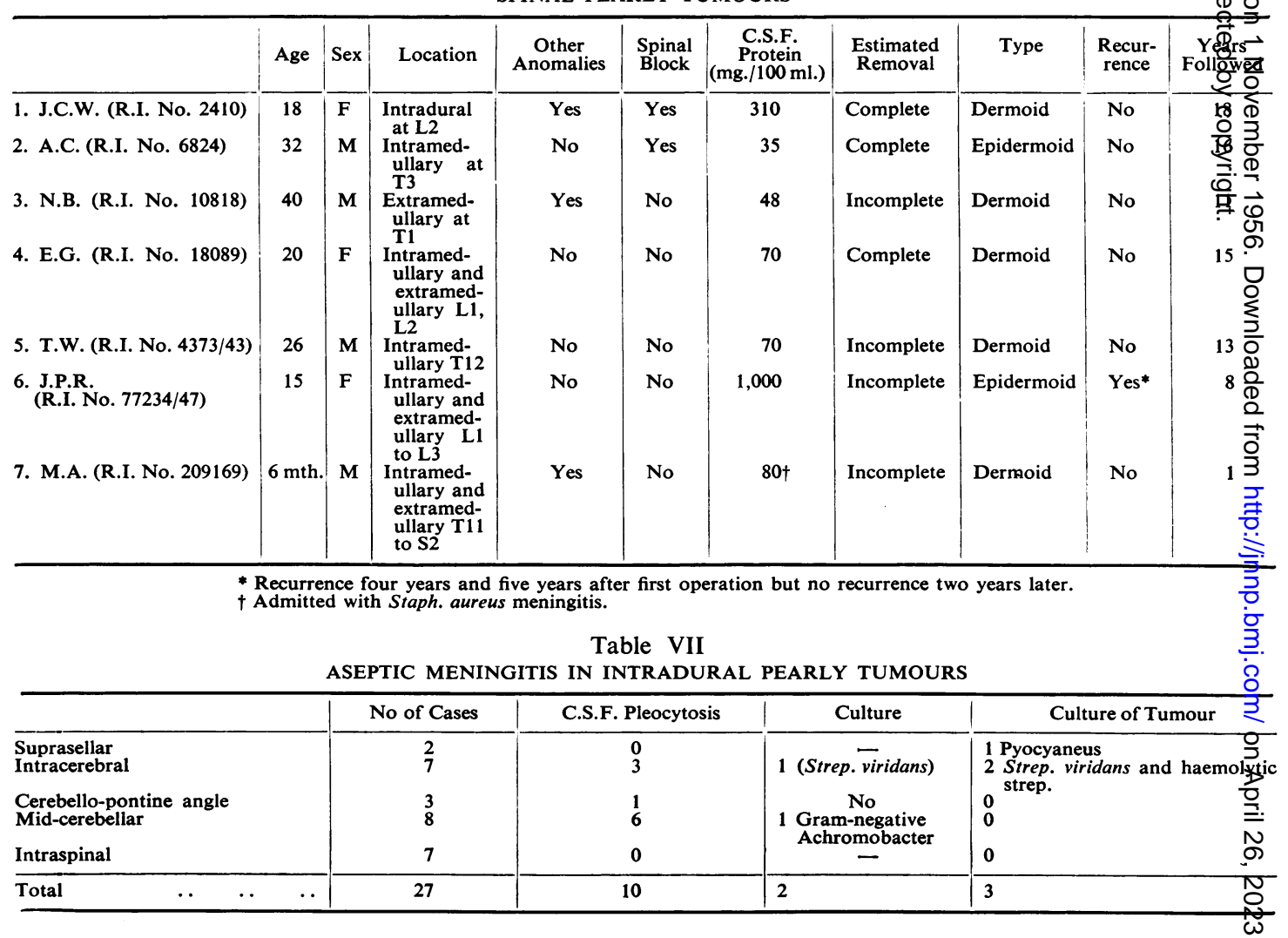




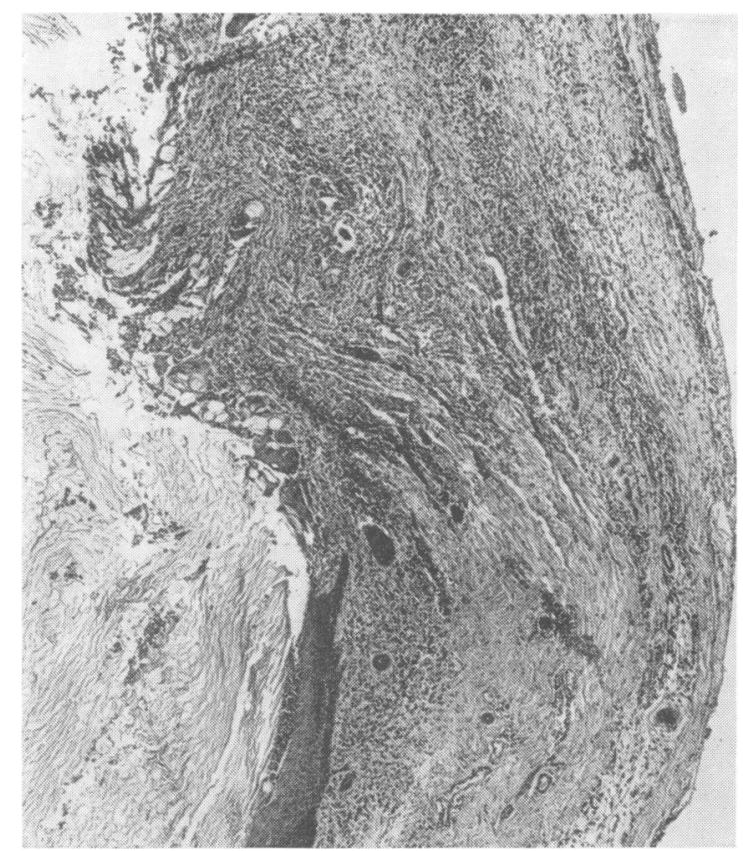

Fig. 23.-Microscopic section of a spinal dermoid (Case 7). There is an extensive inflammatory cell reaction in the dermal layer and a portion of the epidermis has been destroyed. (Haematoxylin and eosin $\times$ 46.)

white cell infiltration of the dermis that destroyed a portion of the epidermal layer (Fig. 23).

These cases are often first seen because of meningitis, at which time there may not be any signs of spinal cord or cauda equina involvement. They are similar to those patients with occipital dermal sinuses and should be treated accordingly (Kahn, Bassett, Schneider, and Crosby, 1955; Walker and Bucy, 1934).

\section{Comment}

In the surgical treatment of the pearly tumours two main problems arise. The first is the occurrence of cerebrospinal fluid pleocytosis or aseptic meningitis during the post-operative period. The second is the question of recurrence.

Aseptic meningitis is a frequent post-operative complication, especially if some of the tumour is left behind. It may persist for weeks and, except for the absence of micro-organisms, the spinal fluid closely resembles that of acute purulent meningitis. There are numerous reports attesting this fact (Bailey, 1920; Critchley and Ferguson, 1928; Grant and Austin, 1950; Mahoney, 1936; Olivecrona, 1932; Peyton and Baker, 1942). It may remain sterile and subside spontaneously, or it may develop into a bacterial meningitis and, as a matter of fact, cultures taken from pearly tumours at the time of operation occasionally grow pathogenic organisms.

Out of 27 cases of intradural epidermoids and dermoids in the present series, 10 developed a cerebrospinal fluid pleocytosis post-operatively (Table VII). Repeated cultures were sterile in eight patients. In one of these (Case 2 of the intracerebral group) the process persisted and eventually a sterile brain abscess occurred which required re-exploration. In two patients a bacterial meningitis developed. In such cases the appearance of organisms may be due either to their delayed growth on culture or to their introduction at lumbar puncture. One patient died four days later. In the other, the process eventually resolved with antibiotic treatment.

In five cases, exclusive of those presenting with meningitis, micro-organisms were cultured from the tumour at the time of operation. One of the growths arose in the petrous bone, however, and might possibly have been related to a chronic middle ear infection. One positive culture was obtained from an orbital dermoid. It is possible, of course, that all five cultures may have been due to contaminants.

Examples of aseptic meningitis resulting from spontaneous leakage of these tumours have been reported (Bauditz, 1933; Essellier, 1945; Lehoczky, 1951). Bauditz (1933) cites three cases in which the cyst contents were found by lumbar puncture after leakage had occurred.

Cholesterin has been incriminated as the inciting cause of aseptic meningitis. Greenfield (1932) believes that it plays an important role in producing the pleocytosis occurring a few days after subarachnoid haemorrhage. He cites the experimental work of Bender, who in 1925 injected various lipoidal fractions obtained from myelin into the subarachnoid space of animals and found that cholesterin produced a much more intense reaction than did the other fractions. This irritating action of cholesterin is also demonstrated by the presence of a foreign body giant cell reaction around cholesterol crystals (Fig. 24).

Bauditz (1933) discussed a case in which a basal dermoid ruptured spontaneously, causing death. Histological sections of the brain revealed numerous giant cells in the ventricular system and subarachnoid space, along with an intense glial reaction. Mahoney (1936) obtained similar findings by injecting cholesterine crystals into the cerebral cortex of dogs.

In an attempt to prevent this complication care should be taken at operation to avoid, as much as possible, contamination of the surrounding region by tumour contents. In this hospital prophylactic 


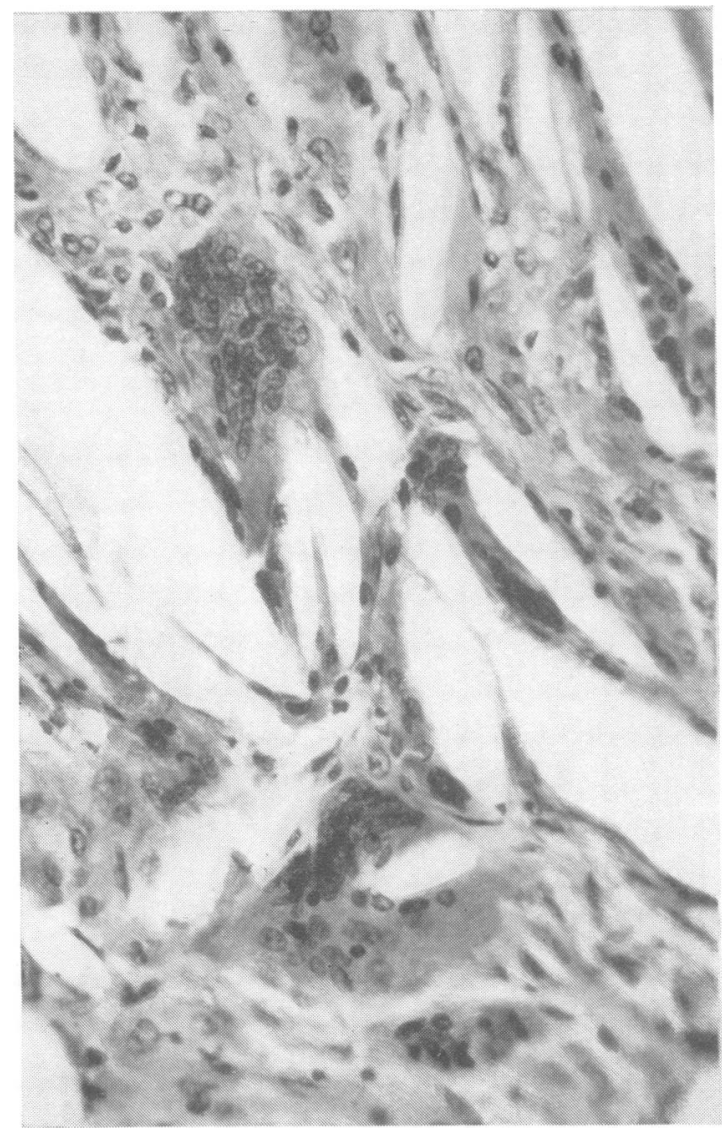

FIG. 24.-Microscopic section of the tumour wall in an epidermoid (Case 5 of the cerebellar group). The clear, cleft-like spaces represent cholesterol crystals that have dissolved out during processing. Many foreign body giant cells can be seen around these spaces. (Haematoxylin and eosin $\times 302$.)

chemotherapy is given for several days after operation. Specimens of the tumour are taken for culture and sensitivity studies. If these are positive the appropriate antibiotic is used.

That these tumours recur following incomplete removal is well known. The capsule constitutes the only living part, and if remnants are left behind growth will continue (Bailey, 1920). However, these lesions are slow-growing, and years may pass before this becomes clinically evident. Sachs (1936) mentioned recurrence in a cerebello-pontine epidermoid 13 years after operation.

Of the 27 intradural tumours in this series removal was believed to have been incomplete in 12 cases. One patient (Case 2) of the intracerebral group died of recurrence 13 years after operation. Recurrence has also taken place in another patient (Case 6) of the spinal group four years and again five years after the first operation. One patie (Case 2 of the cerebello-pontine angle group) may be showing signs of recurrence after eight years, and one of the suprasellar group has shown signs of visual field changes seven years after operation. Recurrence is not known to have occurred in affy of the others who have been followed for an average of about eight years. Removal was believed to hate been complete in the remaining cases, and thus tăr none has recurred.

Total removal should be possible in the majoritity of extradural tumours without damaging vigal structures, and every attempt should be made do so.

In the intradural group, on the other hand, ${ }_{a}$ different situation exists. The capsule may be densêty adherent, or may actually invade vital structures. This is especially true in the suprasellar, cerebeltepontine angle, and intraspinal groups. If this is $\overrightarrow{\mathbf{s o}}$, the tumour contents should be removed and portions of the capsule that come away easily should be excised. Parts adherent to major vessels, or functional nervous tissue, are best left behind. Summary and Conclusions

6

A series is presented of 41 cases of pearly tunaturs related to the central nervous system. This ferm includes epidermoids and dermoids, since, in spite of their difference histologically, their characteris $(\mathrm{Tes}$ are quite similar.

Two patients had pericranial dermoids associated with neurological abnormalities. 产heir aetiology is discussed along with their differenti胥ion from encephalocele.

Six patients had orbital pearly tumours, with proptosis as the main complaint. Visual dist r bances were minimal. The main indication for surgical removal of these growths is a cosmetic one, and good results may be obtained.

Six patients had pearly tumours arising in the petrous bone and presented with peripheral fagal weakness, associated with deafness in five cases. Four had operations, but improved facial negte function occurred in only one patient. Earfier operation should improve these results.

The features of the diploic pearly tumours discussed, notably their characteristic radiolog appearance. Two examples are cited.

Two patients had pearly tumours arising in the suprasellar region and presented with a chiasmal syndrome unassociated with endocrine abnormalit?s. Radiographs of the sella turcica were normal, except for some flattening of the posterior clinoid processes that may not be significant. Total removal of these tumours is hazardous because of their relation to the optic nerves and internal car@id 
arteries. Intracapsular removal is probably preferable, since they recur so slowly.

Seven patients had intracerebral pearly tumours. Epilepsy featured in the history of four of them and may be a prominent characteristic in these cases. The diagnostic significance of air studies in these patients is discussed.

Three patients had cerebello-pontine angle epidermoids and presented with the usual features of tumours in this region. All had normal cerebrospinal fluid proteins, a finding significant in differentiating these tumours from acoustic neurinomas and cerebello-pontine angle meningiomas.

Eight patients had pearly tumours arising in the vermis and fourth ventricle. Three of them had associated dermal sinuses. Their role in the production of meningitis is emphasized, along with the importance of early surgical intervention in all of these cases.

Seven patients had intraspinal (intradural) pearly tumours. Six of them were at least in part intramedullary. Associated dermal sinuses were present in two patients, one of whom presented as a meningitis. When these growths are entangled in the cauda equina, or when they invade the spinal cord, incomplete removal seems advisable to prevent further damage to these structures.

All of the patients with extradural pearly tumours survived operation, and to our knowledge there have been no recurrences in this group.

Of the 27 patients with intradural tumours four died in the immediate post-operative period, a mortality of $15 \%$. Three of these deaths occurred in patients in the cerebellar group and were attributed, at least in part, to late surgical intervention. The other occurred in a patient with a cerebellopontine angle epidermoid.

Aseptic meningitis occurred in 10 patients with intradural pearly tumours. Repeated spinal fluid cultures were sterile in eight cases, although one of them later developed a sterile brain abscess requiring re-exploration. Two patients developed a bacterial meningitis, which was fatal in one of them. This complication is discussed, with reference to other recorded examples.

Recurrence is discussed in reference to the intradural group. Although removal was incomplete in at least 12 patients, known recurrence has taken place in only two of them, four and 13 years postoperatively. Two other patients may be showing signs of recurrence eight and seven years after operation. The remaining patients in this group have been followed for an average of eight years.

We wish to acknowledge our gratitude to Dr. Peter Daniel and Dr. Sabina Strich, of the Department of
Neuropathology, for their help and advice concerning the pathology of these tumours together with the photomicrographs which were produced in their department, and to Dr. Philip Sheldon, of the Department of Radiology, who was instrumental in selecting the radiographs reproduced above. We are also indebted to Mrs. Joyce Gilbert for her help in gathering literature and preparing the manuscript.

\section{REFERENCES*}

Bailey, P. (1920). Surg. Gynec. Obstet., 31, 390.

Baile (1924). Arch. Surg. (Chicago), 8, 524

Bauditz, A. (1933). Z. ges. Neurol. Psychiat. (Orig.), 144, 135. Bostroem, E. (1897). Zbl. allg. Path. path. Anat., 8,1.

Brock, S., and Klenke, D. A. (1931). Bull. neurol. Inst., N.Y., 1, 328.

Childe, A. E., and Young, A. W. (1947). Radiology, 48, 56.

Critchley, M., and Ferguson, F. R. (1928). Brain, 51, 334.

Cruveilhier, J. (1829). Anatomie Pathologique du Corps Humain. Vol. I, Book 2, Plate 6. Baillière, Paris.

David, M., Lacroix, A., Thierry, S., and Brun, M. (1936). Rev. neurol. (Paris), 65, 379.

Dyke, C. G., and Davidoff, L. M. (1937). Bull. neurol. Inst., N.Y., 6, 489.

Ernst, P. (1912). Verh. dtsch. path. Ges., 15, 226.

Essellier, A. (1945). Schweiz. Z. allg. Path. Bakt., 8, 41.

Findeisen, L., and Tönnis, W. (1937). Zbl. Neurochir., 2, 301.

Floris, V., and Castorina, G. (1950). Riv. Neurol., 20, 303.

Gonzalez Revilla, A. (1947). J. Neurosurg., 4, 233.

(1 348). Bull. Johns Hopk. Hosp.. 83, 187.

Grant, F C., and Austin, G. M. (1950). J. Neurosurg., 7, 190.

Greenfield, J. G. (1932). In Cytology and Cellular Pathology of the Nervous System, ed. W. Penfield, Vol. 3, p. 1224. Hoeber, New York.

Harvey, S. C., and Burr, H. S. (1926). Arch. Neurol. Psychiat. (Chicago), 15, 545.

Horrax, G. (1922). Ibid., 8, 265.

-, Yorshis, M., and Lavine, G. R. (1935). Ibid., 33, 1058.

Hug, O. (1942). Virchows Arch. path. Anat., 308, 679.

Jefferson, G., and Smalley, A. A. (1938). J. Laryng., 53, 417.

Kahn, E. A., Bassett, R. C., Schneider, R. C., and Crosby, E. C. (1955). Correlative Neurosurgery, p. 380. Thomas, Springfield, Ill

King, J. E. J. (1939). Ann. Surg., 109, 649.

Körner (1900). Z. Ohrenhrilk., 37, 352, Cited by Rosenwasser.

Lehoczky, T. de (1951). Acta neurol. psychiat. belg., 51, 319.

Lewis, M. L., and Echols, D. H. (1951). Laryngoscope (St. Louis), $61,1123$.

List, C. F. (1941). Surg. Gynec. Obstet. 73, 525.

Logue, V., and Till, K. (1952). Journal of Neurology, Neurosurgery and Psychiatry, 15, 1.

Love, J. G. and Kernohan, J. W. (1936). J. Amer. med. Ass., 107, 1876.

Mahoney, W. (1936). Z. ges. Neurol. Psychiat. (Orig.), 155, 416.

Martel, T. de, and Guillaume, J. (1938). Rev. Neurol. (Paris), 69, 384.

Matson, D. D., and Ingraham, F. D. (1951). Pediatrics, 8, 463.

Montgomery, G̈. L., and Finlayson, D. I. C. (1934). Brain, 57, 177.

Müller, J. (1838). Ueber den feinern Bau und die Formen der krankhaften Geschwulste. Reimer, Berlin.

Olivecrona, H. (1932). Brain, 55, 122.

(1949). Acta Psychiat. (Kbh.), 24, 639.

Paleari, A. (1939). Riv. Neurol., 12, 185.

Pennybacker, J. (1944). Brit. J. Surg., 32, 75.

Peyton, W. T., and Baker, A. B. (1942). Arch. Neurol. Psychiat. (Chicago), 47, 890.

Rand, C. W., and Reeves, D. L. (1943). Arch. Surg. (Chicago),

Raskin, N. (1949). J. Neurosurg., 6, 534.

Remak, von (1854). Cited by Critchley and Ferguson, p. 337.

Rosenwasser, H. (1935). J. Mt Sinai Hosp., 2, 56.

Sachs, E. (1936). In discussion, see Love, J. G. and Kernohan, J. W., p. 1883.

Jr., and Horrax, G. (1949). J. Neurosurg., 6, 97.

Schoen, H. (1939). Röntgenpraxis, 11, 62.

Sheldon, P. W. E., Wickbom, I., and Pennybacker, J. B. (1953). J. Fac. Radiol. (Lond.), 4, 275.

Simpson, R. R. (1954). Proc. roy. Soc. Med., 47, 205.

Stromeyer, F. (1909). Beitr. path. Anat., 47, 392.

Verattus (1745). Cited by Critchley and Ferguson, q.v. (1928)

Virchow, R. (1855). Virchows Arch. path. Anat., 8, 371.

Walker, A. E., and Bucy, P. C. (1934). Brain, 57, 401.

Weinberger, L. M. (1938). J. Mt Sinai Hosp., 5, 565.

* Copies of a more complete bibliography are available on application to either of the authors. 